\title{
Shadow Banking: The Blind Spot in Banking and Capital Markets Reform
}

\author{
by
}

David Ramos MuÑoz*

\begin{abstract}
"Shadow banking" is the concept used by the Financial Stability Board (FSB) and the European Commission to propose a new bout of regulatory reforms. The problem of this concept is less in its negative bias than in the fact that it mischaracterizes and marginalizes the problem. Rather than an issue of market players avoiding the rules, shadow banking's is a story of market players exploiting the rules and institutional structures created for their benefit. Rather than a separate 'parallel' system, shadow banking encompasses major players and markets, and has become the system, thanks partly to policy choices. The phenomenon of shadow banking should prompt a deeper discussion about the influence of legal institutions in market structures, and the perils of artificial distinctions between 'banking/money markets' and 'capital markets'. Drawing the appropriate lessons is particularly important now that momentous reforms, such as the Banking Union and Capital Markets Union, seem to go back to traditional (and unrealistic) dividing lines.
\end{abstract}

Table of Contents

ECFR 2016, 1-40

I. Introduction $\ldots \ldots \ldots \ldots \ldots \ldots \ldots \ldots \ldots \ldots \ldots$

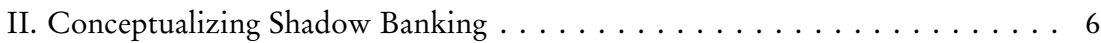

1. The old, the new, and the State. The need for an institutional approach that considers banking/money interactions with the law . . . . . . 7

2. Applying the institutional approach to shadow banking perspectives . . . . 9

III. Shadow Banking: A Critical Appraisal of Reforms . . . . . . . . . . . . . 19

1. Intermediation reforms. Shadow banking, legal interpretation and con-

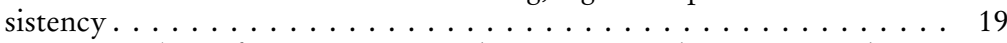

2. Money market reforms. Institutional, monetary and constitutional im-

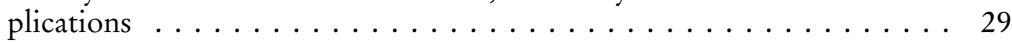

3. Shadow banking's preliminary implications for the Banking Union, Capital Markets Union, and EU institutional architecture . . . . . . . . . 34

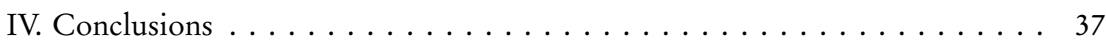

* Senior Lecturer (Profesor Ayudante Doctor) of Commercial Law at the Universidad Carlos III de Madrid. 


\section{Introduction}

Policymaking bodies normally resist the temptation of using literary figures to coin their policies. Thus, the fact that the Financial Stability Board (FSB) or the European Commission decided to encompass a new set of policies under the name of "shadow banking" ${ }^{1}$ should give one pause for thought. Is this a good thing?

To put this in perspective, it is not the first time that moral/literary images are used in the context of financial law. F.D. Roosevelt sold the reform of the Glass-Steagal Act by using the contrast between "productive" and "speculative" banking, ${ }^{2}$ not by talking about prudential regulation or systemic stability. The Securities Act of 1933 was promoted as an act to promote "truth" (e.g. not "efficiency" 3 ). Thus, history suggests that there is no harm in spicing up the language a bit.

Furthermore, the language used in shadow banking policy proposals is as grey as possible. The more stable definition of "shadow banking", in FSB papers is "a system of credit intermediation that involves entities and activities outside the regular banking system, and raises i) systemic risk concerns, in particular by maturity/liquidity transformation, leverage and flawed credit risk transfer, and/or ii) regulatory arbitrage concerns", ${ }^{4}$ hardly a literary exercise. Furthermore, the definition accurately identifies the tenets of credit intermediation

1 FSB The Seoul Summit Document, November 2010, para. 41; European Commission Green Paper. Shadow Banking, 19 March 2012, COM(2012) 102 final; and Communication from the Commission to the Council and the European Parliament Shadow Banking Addressing New Sources of Risk in the Financial Sector Brussels, 4. 9.2013 COM (2013) 614 final. See also FSA The Turner Review A regulatory response to the global banking crisis March 2009 p. 16; Final Report of the National Commission on the Causes of the Financial and Economic Crisis in the United States (The Financial Crisis Inquiry Report) 2011, p. 8388; De Larosiere Report Brussels, 25 February 2009 p. 7. The term was coined by Paul McCulley, a senior executive at PIMCO, and has been echoed ever since in academic studies, policy papers, and press. See The Economist "Special Report. Shadow Banking” May 10th 2014.

2 A bank not put the money into a safe deposit vault; but, rather, puts your money to work to keep the wheels of industry and of agriculture turning around Address of President Roosevelt On the Bank Crisis March 12, 1933. This was one of Roosevelt's "fireside chats". It is worth mentioning that the title of the Banking Act was "An Act to provide for the safer and more effective use of the assets of banks, to regulate interbank control, to prevent the undue diversion of funds into speculative operations, and for other purposes".

3 The Act came to be known as the "Truth in Securities Act". One could also add the contrast between the "small investor" and the "corporate criminal", describing the Enron and WorldCom scandals accompanied the Sarbanes-Oxley Act.

4 FSB Shadow Banking: Strengthening Oversight and Regulation. Recommendations of the Financial Stability Board, 27 October 2011 p. 1. 
that pose the greater problems of financial stability, ${ }^{5}$ using as a basis "maturity transformation" (the funding of long-term, illiquid, assets with short-term, liquid, liabilities).

The attempt to conceptualize the problem is accompanied by earnest efforts of measurement and data gathering, which are far from metaphorical. FSB has submitted that non-bank financial intermediaries grew from $\$ 26$ trillion in 2002 , to $\$ 62$ trillion in 2007; and after some decline in 2008, they were already larger in size in 2011 (and keep growing ${ }^{6}$ ). This is roughly a $25 \%$ of the total financial system, and around $50 \%$ of the size of bank assets. ${ }^{7}$ Albeit further efforts are needed to prune the numbers (not all non-bank financial intermediaries can be characterized as shadow banks) the studies have begun to differentiate by country, ${ }^{8}$ and by type of shadow banking entity. ${ }^{9}$

Finally, the FSB and the Commission have crafted plans, which, far from empty rhetoric, provide a structured agenda that divides the problem into four tasks: (i) regulation of banks' interaction with shadow banking entities (indirect regulation); (ii) regulation of shadow banking entities; (iii) regulation of shadow banking activities; and (iv) macroprudential measures. ${ }^{10}$

These tasks gave rise to five workstreams: (1) indirect regulation of shadow banking (undertaken by the BCBS ${ }^{11}$ ), to mitigate spillover effects between

5 This sits in contrast with broader views, which see every single instance of credit creation (even if fully funded by capital) as part of shadow banking The Economist "Shadow and Substance" May 10th 2014; and, in the same number, Special report on Shadow Banking. The articles use examples of P2P, private equity firms, and defines shadow banking by reference to "lending", rather than intermediation.

6 FSB Global Shadow Banking Monitoring Report 2014, 30 October 2014, 2-3 and 8.

7 Ibid p. 2.

8 The US and the euro area have the largest shadow banking system by size, just above $\$ 25$ trillion. Between the two of them they have $80 \%$ of shadow banking assets (they "merely" have $53 \%$ of banking assets). The largest share is in the EU (34\%) and the United States (34\%) though it has been kept steady (with a slight increase) in the EU, whereas it has decreased (from $41 \%$ ) in the US. As a share of total financial assets, it is largest in the Netherlands, the United Kingdom, or Switzerland. FSB Global Shadow Banking Monitoring Report 2014, 30 October 2014 p. 9.

9 Investment funds are, according to the FSB estimates of the global shadow banking system, the biggest category by size (38\%), but include both entities that belong to the shadow banking system, and others that do not. They are distantly followed by brokerdealers (15\%) structured finance vehicles $(8 \%)$, and broker-dealers, finance companies, and MMMFs (6\% each). FSB Global Shadow Banking Monitoring Report 2014, 30 October 2014 p. 13. More granularity is needed, however, to differentiate, for example, those securitization entities that are consolidated in their sponsor balance sheet, and thus within the regulatory perimeter.

10 Ibid p. 15.

11 BCBS Enhancements to the Basel II framework July 2009 
shadow and regular banking; ${ }^{12}$ (2) regulation of Money Market Funds, (undertaken by the IOSCO ${ }^{13}$ ), to reduce the risk of bank-like "runs"; ${ }^{14}$ (3) regulation of "other shadow banking entities" (undertaken by the FSB itself) to define the "functions" of shadow banking's that pose the greater risks, and the policy tools to address them; ${ }^{15}$ (4) regulation of securitization ${ }^{16}$, to align the incentives between originators and investors; ${ }^{17}$ (5) reform of repos and securities lending markets (also by the $\mathrm{FSB}^{18}$ ), to limit the build-up of leverage and the system's instability. ${ }^{19}$

Thus, if reform efforts rely on a rational assessment, where is the harm in using an evocative and slightly literary concept like "shadow banking"? In principle, none; but the problem of "shadow banking" as a concept is not that it is literary, or that it casts a negative light over the phenomenon, but that it mischaracterizes the problem, by making at least three reductionisms:

12 The emphasis was on consolidation of special purpose entities, calculation of exposures to them, prudential requirements for large exposures and capital requirements for banks' investment in funds' equity. Strengthening Oversight and Regulation of Shadow Banking An Integrated Overview of Policy Recommendations pp. 5-6; EU Commission Green Paper. Shadow Banking cit. p. 11.

13 See, for example, IOSCO Policy Recommendations for Money Market Funds Final report October 2012.

14 FSB Strengthening Oversight and Regulation of Shadow Banking An Integrated Overview of Policy Recommendation pp. 6-7; EU Commission Green Paper. Shadow Banking cit. p. 12.

15 The proposals in this field are more tentative, and try to improve supervisors' ability to detect, assess and mitigate the risks. They initially consisted in mapping the system and proposing a high-level policy framework. To map the system the FSB works team cast the net wide, and then narrowed down the list of entities pursuant to (1) size, (2) supervisors' judgment, and assessed their shadow banking risk factors (maturity transformation and/or leverage), concluding that there was still much heterogeneity from jurisdiction to jurisdiction. FSB Strengthening Oversight and Regulation of Shadow Banking An Integrated Overview of Policy Recommendation pp. 8-9; EU Commission Green Paper. Shadow Banking cit. p. 13. Further efforts have resulted in a more comprehensive framework by the FSB. See FSB A Policy Framework for Strengthening Oversight and Regulation of Shadow Banking Entities 29 August 2013.

16 The new rules require the retention by the sponsor of $5 \%$ of securitization exposures, the so-called "skin-in-the-game". See IOSCO Global Developments in Securitization Regulation Consultation Report, June 2012, pp. 48-52.

17 Ibid pp. 48-52. The proposals were introduced in EU prudential rules, as article 405 of Regulation 575/2013 of 26 June 2013 on prudential requirements for credit institutions and investment firms, the Capital Requirements Regulation (hereafter, or "CRR").

18 FSB Strengthening Oversight and Regulation of Shadow Banking. Policy Framework for Addressing Shadow Banking Risks in Securities Lending and Repos, 29 August 2013.

19 Michel Barnier Towards better regulation of the shadow banking system Brussels Conference, 27 April 2012. See also EU Commission Green Paper. Shadow Banking cit. p. 12 . 
- First, the use of a newly minted concept suggests that "shadow banking" is something new, rather than a recurrent episode in financial regulation. This can overlook the lessons of the past, which are critical in devising a solution for the future.

- Second, the focus on "regulatory arbitrage" overlooks the fact that shadow financial intermediation can also result from regulatory subsidies or more complex interactions that resist simplification.

- Third, and most important, by characterizing shadow banking as something that has grown "in the shadow of", or "parallel to" traditional banking the official account an overlook that it is the structure of financial markets, at its core, that has changed.

The problem, in all its complexity, cannot be solved by the simple extension, or fine-tuning, of existing rules, and requires a deeper understanding of the relationship between finance and (legal) institutions. ${ }^{20}$ Such need of reassessment is particularly pressing in the European Union at the present time, where recent reforms have heralded a new era for the unification of financial markets. The first limb of these reforms is the Banking Union, which includes a new Single Supervisory Mechanism (SSM) presided over by the European Central Bank (ECB), ${ }^{21}$ a Single Resolution Mechanism (SRM) administered by the Single Resolution Board ${ }^{22}$ (where the ECB also has a key role ${ }^{23}$ ), and a Single Prudential Rulebook, formed by bank prudential rules, ${ }^{24}$ and developed by the

20 "Institution" is used in the sense of a system of norms or rules that set prescriptive standards of behaviour. See Oliver North Institutions, Institutional Change and Economic Performance, Cambridge: Cambridge University Press, 1990; Geoffrey Hodgson 'What are Institutions?' Journal of Economic Issues, Vol. 40(1) (2006) pp. 2-25. The need to focus on the relationship between finance and the law and State has been reclaimed recently by proponents of the Legal Theory of Finance (LTF). See Katharina Pistor "A Legal Theory of Finance" Journal of Comparative Economics Vol. 41 (2013) pp. 315-330. See the whole volume 41 of the Journal for some of the main contributions to this view, which Simon Deakin calls "new institutional economics". See Simon Deakin 'The legal theory of finance: implications for methodology and empirical research', Journal of Comparative Economics 41 (2013) pp. 338-442.

21 Council Regulation (EU) No. 1024/2013 of 15 October 2013 conferring specific tasks on the European Central Bank concerning policies relating to the prudential supervision of credit institutions (hereafter: SSM Regulation).

22 Regulation (EU) No. 806/2014 of the European Parliament and of the Council of 15 July 2014 establishing uniform rules and a uniform procedure for the resolution of credit institutions and certain investment firms in the framework of a Single Resolution Mechanism and a Single Resolution Fund (hereafter: SRM Regulation).

23 See, e.g. article 18 (1) paras. 2-4 SRM Regulation (assessment of the main requirements that determine whether an entity will be subject to a resolution scheme).

24 See the Directive 2013/36/EU of the European Parliament and of the Council of 26 June 2013 on access to the activity of credit institutions and the prudential supervision of 
European Banking Authority (EBA). ${ }^{25}$ The second, still incipient, limb is the Capital Markets Union, whose agenda has been announced by the European Commission this year. ${ }^{26}$

These reforms signal a moment of triumph for EU public authorities, an actual proof that they can get impressive things done. So who wants to be the killjoy who throws cold water over so much enthusiasm? Yet one needs not diminish these achievements to point out that, despite such major changes in the basement and architecture, it is important not to lose sight of the plumbing, because it was the plumbing what brought us to where we are.

This article argues that the questions raised by shadow banking continue without an answer, and that the danger that such questions are overlooked is greater now that policymakers are busy with grander projects. Yet aside from criticism it also offers a framework of analysis for such questions, one that ensures that emphasizes the fluid connection between finance and the legal institutions underpinning the system. Section II tries to paint a more complete picture of "shadow banking", which is not subject to official simplifications. Section III uses this more complete account for a critical assessment of ongoing reforms, and provide insights that should not be missed. Section IV concludes by arguing strongly for a change of focus.

\section{Conceptualizing Shadow Banking}

This Section first tries to situate shadow banking in an adequate historical context, one that properly reflects the interaction between banking and law/ State (1). In second place, it uses such 'institutional' approach to construe a more complete narrative of shadow banking as symptom of profound changes in financial intermediation and money markets (2).

credit institutions and investment firms, amending Directive 2002/87/EC and repealing Directives 2006/48/EC and 2006/49/EC (hereinafter "CRD") and the Regulation (EU) No. 575/2013 of 26 June 2013 on prudential requirements for credit institutions and investment firms and amending Regulation (EU) No. 648/2012 (hereinafter "CRR").

25 https://www.eba.europa.eu/regulation-and-policy/single-rulebook/interactive-singlerulebook.

26 European Commission Green Paper. Building a Capital Markets Union Brussels, 18.2.2015 COM(2015) 63 final; and Communication. Action Plan on Building a Capital Markets Union. Brussels, 30. 9.2015 COM(2015) 468 final. 
1. The old, the new, and the State. The need for an institutional approach that considers banking/money interactions with the law

The first reductionism of shadow banking is to assume that it is an occurrence of the 2007-2009 crisis, despite the phenomenon, as such, is not new. Banking (understood as maturity transformation and liquidity creation) has always been risky and subject to "runs". The risk has traditionally justified government backstops (deposit insurance or central banks liquidity windows). Government backstops create a moral hazard problem that justifies prudential rules; and those prudential rules create the grounds for funds to flow towards less regulated activities, beginning the cycle again. ${ }^{27}$ History offers many examples: the discount houses and bill brokers, described by Walter Bagehot in his Lombard Street ${ }^{28}$; the Macklerbanken and Baubanken in 1870s' Germany and Austria; ${ }^{29}$ the trust companies in the 1907 US crisis; ${ }^{30}$ the US savings and loans entities in the late 80 ' $s ;{ }^{31}$ or hedge funds, in the late 90 's. ${ }^{32}$

Furthermore, the emphasis of the FSB and the Commission on the "intermediation" perspective misses an important angle of shadow banking. Shadow banking can also consist in the "monetization" of certain assets, and the ensuing growth of credit and leverage, asset bubbles and financial crises. In some cases the "bankarization" of certain entities was accompanied by the "monetization" of those entities' instruments; ${ }^{33}$ but, in other cases, some instruments

27 Charles Goodhart "The Boundary Problem in Financial Regulation” In The Fundamental Principles of Financial Regulation Geneva Reports on the World Economy 11, 2009, pp. 69-70.

28 Walter Bagehot Lombard Street. A Description of the Money Market Third edition, London: Henry S. King \& Co., 1873, Chapter XI pp. 281-301. They had an important role in the 1857 crisis. The most notorious case was that of Sanderson, Sanderman \& Co., which had 3,5 million deposits when it stopped payments. See J. R. T. Hughes Fluctuations in Trade, Industry and Finance-A Study of British Economic Development 1850-1860 London: Oxford University Press, 1960 pp. 302-305. See also W. T. C. King History of the Discount Market London: Routledge and Sons, 1936 p. 69.

29 Charles Kindleberger Manias, Panics and Crashes. A History of Financial Crises. Fifth edition, Wiley, 2005, p. 65.

30 The most notorious example was that of the Knickerbox Company, whose failure spread panic across the system. See Bruner, Robert F.; Carr, Sean D. The Panic of 1907: Lessons Learned from the Market's Perfect Storm, New Jersey: John Wiley \& Sons, 2007 , pp. 68-85.

31 National Commission on Financial Institution Reform, Recovery and Enforcement Origins and Causes of the SEL Debacle: A Blueprint for Reform. A Report to the President and Congress of the United States Washington, DC, 1993

32 Nicholas Dunbar Inventing Money: The story of Long-Term Capital Management and the legends behind it New York: Wiley, 2000.

33 This is what happened with trust companies. See Charles Kindleberger Manias, Panics and Crashes op. cit. p. 65. In its origins the creation of fiat money was largely related to 
were 'monetized' without the bankarization of their issuers, as it happened with the chains of accommodation bills in XVIIIth century Holland. ${ }^{34}$ This, second, perspective, is well-captured by Charles Kindleberger's "two axioms" for crises: axiom number one. Inflation depends on the growth of money. Axiom number two. Asset price bubbles depend on the growth of credit. ${ }^{35}$ The implication for shadow banking is that, when legal institutions are introduced to limit the growth of money, credit and leverage through 'official' channels, the market can 'create money' through unofficial ones.

The fact that shadow banking is not something entirely new does not mean that its latest episode poses no challenges of its own. From an 'intermediation' perspective, unlike previous instances, where less regulated intermediation was concentrated on one or a few types of entities, the 2007-2009 crisis was characterized by the interactions of an unparalleled number of new entities: finance companies, monoline insurers, broker-dealers, money-market funds (MMFs), hedge funds, and an alphabet soup of securitization vehicles ("SPVs", "SIVs", "CDOs", etc) were part of the process. ${ }^{36}$ From a "monetization' perspective, the latest crisis was characterized by the emergence of the repo market, as the key market where financial intermediaries (both banks and non-banks) seek liquidity, and the main source of risk, when such liquidity dries up. ${ }^{37}$ Some academic studies have tried to estimate the size of specific repo markets, ${ }^{38}$ yet repos are absent from the FSB’s Global Shadow Banking Monitoring Reports. ${ }^{39}$

Thus, precedents show that, historically, shadow banking is a byproduct of the complex relationship between money, banking, and the law (understood in a broader sense, as finance's institutional structure). Financial intermediaries are

the official authorization for that money to be used as legal tender so settle debts. See Charles W Calomiris; Stephen H Haber Fragile by Design. The Political Origins of Banking Crises and Scarce Credit op. cit. p. 74-75.

34 Charles Kindleberger Manias, Panics and Crashes op. cit. p. 129.

35 Ibid p. 64.

36 SIVs have disappeared, for example, but Real Esate Investment Trusts (REITs) have acquired renewed importance. See Tobias Adrian; Adam B. Ashcraft; Nicola Cetorelli "Shadow Bank Monitoring" FRBNY Staff Report No. 638 September 2013.

37 For example, Lehman Brothers funded the majority of its balance sheet in the short-term repo market (more than $\$ 200$ billion on a daily basis).. See Report of Anton Valukas. Examiner United States Bankruptcy Court. Southern District of New York. In re Lehman Brothers Holdings Inc. 08-13555 (JMP) March 11, 2010, pp. 3, 63

38 Loriano Mancini; Angelo Ranaldo; Jan Wrampelmeyer "The Euro Interbank Repo Market" Swiss Finance Institute Research Paper No. 13-71 July 30, 2015; Adam Copeland, Darrell Duffie, Antoine Martin, Susan McLaughlin Key Mechanics of the US TriParty Repo Market FRBNY Economic Policy Review forthcoming.

39 See, e.g. the Global Shadow Banking Monitoring Report 2014, available at http:// www.financialstabilityboard.org/wp-content/uploads/r_141030.pdf 
considered by neoclassical economic theory as "black boxes", or a go-between in the middle of savers and borrowers. ${ }^{40}$ Yet historical accounts show that bank "charters" were, in their origins, considered a token of privilege, not an instrument of regulatory control, and that banking structure (and its structural fragility) is a byproduct of its institutions, which are a result of the State's position, and political alliances. ${ }^{41}$

The relationship between "money" and institutions is more hotly contested, with two opposite camps. The 'Metallists' argue that money is a product of social interaction (the use of certain commodities, e.g. gold, develops as a means of reducing transaction costs) and the State does not matter (the State normally validates ex post what society's custom); whereas the Chartalists retort that money acquires its value primarily through legal sanction (when the State indicates that its taxes can be paid through a certain means, those means become money). ${ }^{42}$

Thus, the question is whether the view supported by precedents, which suggests that the State, the law and institutions are often at the core of the problem, is also true with regard to shadow banking's new challenges. The next points discuss this, addressing, first, a micro-prudential perspective that focuses on the "intermediaries", and, then, a macroprudential perspective that focuses on "money".

\section{Applying the institutional approach to shadow banking perspectives}

The problem of shadow banking has been put in context, and it is suggested that the adequate approach is one that gives due consideration to the connection between institutions and banking-money to explain the specific narratives and examples of shadow banking. This Section does that, beginning with

40 For an account that compares this traditional view with a more modern one, see Joseph Stiglitz; Bruce Greenwald Towards a New Paradigm of Monetary Economics Cambridge University Press, 2003.

41 Charles W Calomiris; Stephen H Haber Fragile by Design. The Political Origins of Banking Crises and Scarce Credit Princeton University Press, 2014, p. 73.

42 See Stephanie Bell "The role of the State and the hierarchy of money" Cambridge Journal of Economics Vol. 25 (2001) pp. 151 et seq; Charles Goodhart "The two concepts of money: implications for the analysis of optimal currency areas" European Journal of Political Economy Vol. 14, Issue 3 (1998) pp. 407-432. Well-known proponents of the "metallist" school are Karl Menger "On the origin of money" Economic Journal Vol. 2 no. 6 (1892) pp. 239-255; or Ludwig v Mises The Theory of Money and Credit New Haven: Yale University Press, 1953, pp. 30-38, 68-79. For proponents of the chartalist school, see G Knapp The State Theory of Money London: Routledge, 1924; Hyman Minsky Stabilizing an Unstable Economy New Haven: Yale University Press, 1986. 
micro-prudential narratives, based on "intermediaries" (A), and then moving to macro-prudential narratives based on "money" and money markets (B).

\section{A. The institutional approach applied to the 'intermediation' perspective.}

An article by Pozsar, Tobias, Ashcraft and Boesky ${ }^{43}$ formulated the first approach to model shadow banking dynamics and risk. The idea was that, unlike traditional banking, where maturity, liquidity and credit transformation are concentrated in the balance sheet of a single entity, modern shadow banking had disintegrated the process in pieces, ${ }^{44}$ with separate institutions "specializing" in each function. ${ }^{45}$

These entities created safe, short-term and liquid assets through the packaging and re-packaging of less safe, long-term, and illiquid cash flows from the primary credit market, in a risk-stripping process. ${ }^{46}$ The actual names of the entities involved (which have already changed after the crisis ${ }^{47}$ ) is less important than the fact that so many were part of a "process", or "chain" of functions, that resulted in decentralized credit creation. Some entities specialized in originating credit, others in storing and repackaging it, others in trading it, and

43 Zoltan Pozsar; Tobias Adrian; Adam Ashcraft; Hayley Boesky Shadow Banking op. cit.

44 Ibid p. 5.

45 According to their analysis, those functions were: (1) loan origination (typical of finance companies, funded through commercial paper (CP) and notes); (2) loan warehousing (typical of conduits, and funded through asset-backed commercial paper (ABCP); (3) pooling and structuring of loans into term asset-backed securities (ABS) (typically by broker-dealers' ABS syndicate desks, and funded through SPV-issued ABS); (4) ABS warehousing (typically in trading books, and funded through repo, TRS or hybrid conduits); (5) pooling and structuring of ABS into CDOs (typically done (again) by broker-dealers' ABS syndicate desks); (6) ABS intermediation (typically done by limited purpose finance companies (LPFCs), structured investment vehicles (SIVs), securities arbitrage conduits and credit hedge funds, funded in very different ways, such as with repos, ABCPs, medium-term notes (MTNs), bonds and capital notes; (7) funding in the wholesale funding markets (typically done by MMMFs, regulated under Section 2 (a)-7 of the Investment Company Act (short-term financing), or even mutual funds, pension funds or insurance companies (medium-term financing). Zoltan Pozsar; Tobias Adrian; Adam Ashcraft; Hayley Boesky Shadow Banking op. cit. pp. 10-11.

46 Stijn Claessens, Zoltan Pozsar, Lev Ratnovski, and Manmohan Singh Shadow Banking: Economics and Policy IMF Staff Discussion Note, December 4, 2012 SDN/12/12, pp. 7-8.

47 More recent studies conclude that some of the players do not exist today, but that this does not eliminate the overall structural problem of the division of traditional banking across a chain of functions. See Tobias Adrian; Adam B. Ashcraft; Nicola Cetorelli "Shadow Bank Monitoring" FRBNY Staff Report No. 638 September 2013 pp. 16-20. 
others in providing wholesale funding. The complexity led investors to cease focusing on the actual risks, and to 'trust the process'. ${ }^{48}$

Is it possible to draw conclusions using an institutional approach? Let us consider the types of institutions one by one. To begin with, securitization in the United States would not be the same without Government-Sponsored Enterprises (GSEs) Fannie Maw, Freddie Mac and Ginnie Mae. These entities were purportedly private, but in practice had government backing; they engaged in credit intermediation, yet they were subject to weaker supervision. This was not regulatory arbitrage, but a deliberate (or, at least, implied) policy choice: the government chose to sacrifice soundness and stability for a social goal such as an improved access to credit. ${ }^{49}$ This kind of trade-off is extremely common in finance, ${ }^{50}$ but any useful lessons may be overlooked if one insists on a narrower narrative of shadow banking. ${ }^{51}$

48 Kindleberger emphasizes that there is a point in every bubble where the "objective becomes the process". See Charles Kindleberger Manias Panics and Crashes op. cit. p. 45. In our case this would have been the point when, rather than calculating profits by comparing the instruments' expected cash flows with their "credit risk" (i.e. the probability of default and loss in case of default) entities began focusing on the expected profit of resale.

49 Financial Crisis Inquiry Commission. A Report on the Causes of the Financial Crisis, 2011, pp. 38-40. See also David Reiss "Fannie Mae and Freddie Mac and the Future of Federal Housing Finance Policy: A Study of Regulatory Privilege" Alabama Law Review Vol. 61 (2010) p. 914; Reginald O’ Shields "Reforming America's Mortgage Market: What Comes after Fannie Mae and Freddie Mac" North Carolina Banking Institute Vol. 16 (2012) pp. 109-110.

50 If one changes from the packaging and guaranteeing of credit to the 'origination' end of the chain, the story is not very different from that of Spanish savings banks (cajas). Their origins as a sort of foundations with charitable purposes resulted in an odd governance structure. Santiago Carbó Valverde; Antonio Palomares Bautista; Victoriano Ramírez González "La regulación de los órganos de gobierno de las cajas de ahorros: consideraciones electorales "Hacienda Pública Española/Revista de Economía Pública, Vol. 171-(4/2004) pp. 33-55. This rendered some of them impervious to market discipline and vulnerable to political influence. Politicized cajas were much likelier to lower lending standards. See Vicente Cuñat; Luis Garicano "Did Good Cajas Extend Bad Loans? The Role of Governance and Human Capital in Cajas' Portfolio Decisions" October19, 2009; Manuel Illueca, Lars Norden, Gregory F. Udell "Liberalization, Bank Governance, and Risk Taking" November 16, 2011, pp.14-22. See also Crespí, R., M. García-Cestona, and V. Salas "Governance mechanisms in Spanish banks: Does ownership matter?" Journal of Banking and Finance Vol. 28 (2004) pp. 2311-2330; V. Salas; J. Saurina "Credit risk in two institutional regimes: Spanish commercial and savings banks" Journal of Financial Services Research Vol. 22 (2002) pp.203-224; V. Salas; J. Saurina "Deregulation, market power and risk behaviour in Spanish Banks" European Economic Review Vol. 47 (2003) pp. 1061-1075.

51 Spanish cajas are not often considered part of the problem of 'shadow banking', because they were subject to the same prudential rules as banks, and Spanish banks were solid. 
Then, let us consider an example that fits better the 'regulatory arbitrage' definition, such as money market funds (MMFs). They operate 'accounts' similar to bank accounts, and are thus subject to a bank-like risk of 'runs'.52 Yet their rise to prominence in the United States was, to a certain extent, tolerated, because they were a reaction to Regulation Q, a controversial rule that capped the interest rate offered on deposits, and was eventually derogated. ${ }^{53}$ Although MMFs are an instance of regulatory arbitrage, the original problem was in the rules, not the arbitrage.

These instances are not endemic to developed markets. Currently, the Chinese shadow banking system is moderate in size, but has experienced the fastest growth of all countries. One of the more prominent shadow banking entities are Wealth Management Products (WMPs) investment funds that offer better returns than bank deposits. It is not surprising that bank deposits are subject to rigid interest rate caps (not unlike Regulation Q). ${ }^{54}$ Nor is it surprising that, despite central government's emphasis on limiting credit growth, this is spurred by local governments, which issue debt through Local Governments Finance Vehicles (LGFVs) another prominent type of Chinese shadow banks. ${ }^{55}$

Finally, consider the tool that linked them all: securitization, which has enjoyed the most prominent spot in shadow banking official accounts. It consists in

See See EBA 2014 EU-wide stress-test results. Available at http://www.eba.europa.eu/ risk-analysis-and-data/eu-wide-stress-testing/2014/results. However, this example shows that sound prudential rules are no substitute for market discipline. The narrower 'shadow banking' focus prevents us from drawing this lesson, despite the fact that examples of trade-offs similar to those of the cajas or GSEs are widespread. See La Porta, R., F. Lopez-de-Silanes, and A. Shleifer "Government ownership of banks" Journal of Finance Vol. 57 (2002) pp. 265-301; H. Hau; M. Thum "Subprime-Related Losses and Board (In-)Competence: Private vs. Public Banks in Germany" Economic Policy Vol. 24 (2009) pp. 701-752.

52 International Organization of Securities Commissions (IOSCO) Policy Recommendations for Money Market Funds Final report October 2012; International Monetary Fund (IMF) Global Financial Stability Report Sovereigns, Funding, and Systemic Liquidity 2010 , pp. 58, 60, 64-68, 75-76.

53 R. Anton Gilbert "Requiem for Regulation Q: What it did and Why it Passed Away" Federal Reserve Bank of St. Louis February 1986, pp. 29-30, 32-33.

54 Douglas Elliott; Arthur Kroeber; Yu Qiao "Shadow banking in China: A primer" Brookings Institution Economic Studies March 2015, pp. 1, 4.

55 Kenji Ueda; Yuko Gomi "Shadow Banking in China and Expanding debts of Local Governments" Institute for International Monetary Affairs pp. 5-6. See also Jianjun Li; Sara Hsu "Shadow Banking in China: Institutional Risks" Political Economy Research Institute WP Series, No. 334 August (2013), pp. 5-6, 8; Jianjun Li; Sara Hsu "Shadow Banking in China: Institutional Risks" Political Economy Research Institute WP Series, No. 334 August (2013), pp. 8-10. 
taking assets out of a bank's portfolio, selling them to a Special Purpose Vehicle (SPV) repackaged as notes or securities, not subject to their sponsor's bankruptcy risk. ${ }^{56}$ Some banks used it to put assets off-balance sheet, and exclude them from Basel capital requirements, but, when the crisis stroke, they bailedout their vehicles. ${ }^{57}$ Others, knowing that they would not bear the risks of securitized assets, lowered lending standards. ${ }^{58}$ Yet none of these pathological uses should obscure the fact that securitization, as such, offers an unparalleled means to mobilize credit and increase liquidity, by facilitating asset partitioning and cash flow insulation. This is why securitization was supported by specific statutory rules that facilitated (i.e. not restricted) bankruptcy-remoteness, ${ }^{59}$ both in civil law countries, ${ }^{60}$ and common law countries. ${ }^{61}$

56 See David Ramos Muñoz The Law of Transnational Securitization Oxford University Press, 2010.

57 Shannon D. Harrington; Elizabeth Hester "Citigroup Rescues SIVs With \$58 Billion Debt Bailout (Update5)" December 14, 2007, available at

58 Atif Mian \& Amir Sufi, The Consequences of Mortgage Credit Expansion: Evidence from the U.S. Mortgage Default Crisis The Quarterly Journal of Economics 124 (4) (2009) pp. 1449-1496. Benjamin J. Keys, Tanmoy Mukherjee, Amit Seru \& Vikrant Vig, "Did Securitization Lead to Lax Screening? Evidence From Subprime Loans" The Quarterly Journal of Economics (2010) 125 (1): pp. 307-362.

59 See David Ramos Muñoz "Bankruptcy-remote transactions and bankruptcy law-a comparative approach (part 1): changing the focus on vehicle shielding" Capital Markets Law Journal (2015) 10 (2) pp. 239-274. See also "Bankruptcy-remote transactions and bankruptcy law - a comparative approach (part 2): can parties validly waive bankruptcy proceedings?” Capital Markets Law Journal (2015) 10 (3) pp. 362-389.

60 Articles 15-17 Spanish Act 5/2015 (formerly article 6 Spanish Act 19/1992, and Article 12 et seq Spanish Royal Decree 926/1998); articles 2 and 6 (2) Luxembourg Securitization Act 2004; articles 9 (1) and 15 (1) Portuguese Decree-Law 453/99; articles L21449-1 et seq of French Financial and Monetary Code. In some cases, this included validating the sale of future assets, generally not subject to property effects. See, for example, article 15 (1) (a) Spanish Act 5/2015 (formerly article 2 (1) of Spanish Royal Decree 926/1998).

61 In the United States, Section 912 US Bankruptcy Reform Act; 107th Congress $\$ 912$ (2001); House of Representatives 333, which modified Section 541 of Bankruptcy Act. This Act could not pass at a federal level, in part because the Enron scandal raised suspicions about SPV-related transactions. Then, reforms were passed at a state level in Texas and Louisiana (which apply to every sale of receivables), and in Delaware, Nevada or Alabama, where rules are restricted to transfers made in the context of a securitization transaction. See Kenneth Kettering True Sale of Receivables: A Purposive Analysis ABI L. Rev. 519 Vol. 16 (2008) pp. 519 et seq. In the United Kingdom, Section 72 of Insolvency Act 1986, introduced by Section 250 of the Enterprise Act 2002, in its letter $\mathrm{A}$, has almost eliminated the regime of receivership, in favor of the more rescuefriendly administration, but its letter $\mathrm{B}$, has introduced an important "capital markets exception", especially conceived for securitizations. See Guy O'Keefe and Andrew Beejay Slaughter \& May A QEA guide to securitisation in the UK (England and Wales) February 2010, p. 12. 
Thus, a closer institutional look reveals that the 'regulatory arbitrage' narrative is too simplistic. The differences in regulatory rules applicable to equivalent activities, and other inconsistencies that are defined as 'shadow banking' often reflect the tensions and discrepancies over the positive and negative effects of a specific type of financial intermediaries.

\section{B. The institutional approach applied to the 'monetization' perspective: from shadows to core}

Like the trees that do not let us see the forest a perspective focused on the individual intermediaries may not let us see their interactions and the risks that build up within the system, ${ }^{62}$ hence the need to supplement it with a 'macro' perspective that looks at the dynamics of money markets. Studies have shown that these were characterized by the use of repos to generate money-like claims. ${ }^{63}$ Both banks and shadow banks regularly resort to repo markets for these purposes.

The pathologies that led to an uncontrolled growth of credit were a result of the increase of the type of collateral that could be used for these purposes (which was expanded from government bonds to securitized assets) and of the re-use of collateral (so-called re-hypothecation) which gave rise to "collateral chains". ${ }^{64}$ The "velocity" of collateral circulation ${ }^{65}$ increased the amount of money-like claims and leverage. It also exposed the main players, dealer banks, who re-used their clients' assets to the claims of those clients, and exposed depository banks to contagion. ${ }^{66}$

62 This is the so-called 'fallacy of composition'. Entities can adopt decisions that are individually rational to keep themselves safe, but that collectively undermine the system. The Fundamental Principles of Financial Regulation. Geneva Reports in the World Economy 2009, p. 1.

63 Stijn Claessens, Zoltan Pozsar, Lev Ratnovski, and Manmohan Singh Shadow Banking: Economics and Policy IMF Staff Discussion Note, December 4, 2012 SDN/12/12.

64 Dealer banks source collateral. They receive it from parties that require funding, or from agents that want to enhance their return by "renting out" their assets as collateral [...] Then, collateral is pledged to other parties to obtain funding or support other contracts. This starts a system of repeated re-use of collateral where a single unit can support multiple transactions. Stijn Claessens, Zoltan Pozsar, Lev Ratnovski, and Manmohan Singh Shadow Banking: Economics and Policy cit. p. 15.

65 Singh, Manmohan, and Peter Stella "Money and Collateral," IMF Working Paper No. 12/95 (2012).

66 Stijn Claessens, Zoltan Pozsar, Lev Ratnovski, and Manmohan Singh "Shadow Banking: Economics and Policy" cit. p. 17. See also Manmohan Singh "Puts in the Shadows," IMF Working Paper No. 12/229 (2012). 
Mehrling et al used this development to define shadow banking as "money market funding of capital market lending" ${ }^{67}$ and emphasize the growth of "private money" alongside "public money" as its defining trait. This factor made the market reliant on an unstable supply of credit (based on volatile expectations on the returns of long-term assets). ${ }^{68}$ Pozsar deepens into this narrative, to describe how money markets have changed. Far from the neat division between what is money, and what is not, one can see a range of assets with varying degrees of "moneyness", which include 'public' assets, 'private' assets, and 'public-private' (or private-public') assets. ${ }^{69}$

These narratives suggest that both the assets' 'moneyness', and the current structure of money markets is a hybrid product of the interaction between market forces and the law, ${ }^{70}$ which has led to a more de-centralized, uncontrolled, and volatile process of credit creation.

67 Perry Mehrling; Zoltan Pozsar; James Sweeney; Daniel H Neilson "Bagehot was a Shadow Banker: Shadow Banking, Central Banking, and the Future of Global Finance" (December 6, 2013) p. 2.

68 In line with Ralph George Good and Bad Trade: an inquiry into the causes of trade fluctuations London: Constable and Company, 1913, and Hyman Minsky Stabilizing an Unstable Economy 1986, pp. 194-219. See also Charles Kindleberger Manias Panics and Crashes. A History of Financial Crises op. cit. p. 25.

69 The first level would include Currency and Central Bank Reserves, but also Treasury Bills; (2) a second level would include private instruments with explicit public (credit and liquidity) backstops, such as retail deposits. More importantly, the next levels would include the "shadow monetary base", which would begin where conventional money measures (M0-M2) end: they would comprise a (3) third level, the so-called "publicprivate" money, or "public shadow money", without explicit public backing, but with an implicit one, arising from the type of assets that back the claim (such as Treasuries, in Treasury repos of Dealer Banks' Government desks; or CNAV shares of Governmentonly MMFs), and (4) a fourth level, with the "purely private" money, or "private shadow money", formed by repos backed by non-government assets in Dealer Banks' Credit Desks, and CNAV shares of "prime" MMFs, and, in last place, uninsured deposits (exceeding the limits of deposit insurance). Zoltan Pozsar "Shadow Banking: The Money View" OFR Working Paper (July 2014). The paper is accompanied by an Appendix with a graphical explanation, "How the Financial System Works. A Map of Money Flows in the Global Financial Ecosystem” July 2014. The access to assets and sources also establishes a certain hierarchy among the system's participants, in the sense that central bank reserves is money for banks, T-repos with banks is money for dealers, and T-repos with dealers is money for MMFs.

70 This is the main proposition of Katharina Pistor's Legal Theory of Finance (LTF). See Katharina Pistor "A Legal Theory of Finance" Journal of Comparative Economics Vol. 41 (2013) pp.315-330, as well as Vol. 41 of the Journal of Comparative Economics, which is entirely dedicated to this issue. See also Perry Mehrling "The inherent hierarchy of money" in Fetschrift for Duncan Foley New York, 2012. 
It is not difficult to see the connection between this process, and the market's institutional structure. Traditionally, the system of fractional reserve banking was conceived to grant some degree of control over the quantity of money that could be created, which gave rise to the academic concept of the 'money multiplier'. ${ }^{71}$ Modern central banking shows that such constructs are a 'myth': central banks no longer target money aggregates, but long-term interest rates, and they do so through the announcement of policy rates. They primarily use open market operations (OMOs) to manage liquidity and avoid extreme rate spikes, but not as a customary way of setting interest rates indirectly by adjusting the quantity of money. ${ }^{72}$

The consequence is that, contrary to the academic description of banks as a 'go-between' that intermediates between savers and borrowers, and uses the formers' money to lend to the latter, banks 'create money'. In fact, they are the driving force behind money creation. Moreover, they do so by first identifying investment opportunities, and, then, funding them with money-like liabilities. The volume of loans determines the volume of deposits, not the opposite, ${ }^{73}$ and central banks have no control over this process. Capital requirements, not reserve requirements, are the only means left to limit credit growth. ${ }^{74}$

If public authorities have lost control over money/credit creation at the core of the system, it should not be surprising that, when it comes to unconventional money-creation channels, such as repos, policymakers are not even fully aware of the market's size, structure, and dynamics. But this, too, is partly explained by the institutions underpinning modern money markets, and the conscious or unconscious policy choices they reflect.

To begin with, shadow banking as a 'market' phenomenon is inextricably linked to the balance sheet expansion and contraction of dealer (i.e. not commercial) banks. ${ }^{75}$ The rise to prominence of dealer banks is not a product of chance. For years central banks' have been executing their operations (repos, purchases or sales of government bills, bonds or securities) through the same dealer banks, which, in most cases, are a select and narrow group of financial

71 Paul Krugman; Robin Wells Macroeconomics Worth Publishers, 2009, Chapter 14: Money, Banking, and the Federal Reserve System: Reserves, Bank Deposits, and the Money Multiplier, pp. 393-396.

72 Piti Disyatat "Monetary policy implementation: Misconceptions and their consequences” BIS Working Papers No. 269 (2008), p. 6.

73 Michael McLeay; Amar Radia; Ryland Thomas "Money creation in the modern economy” Bank of England Quarterly Bulletin Q1 (2014) pp. 14-27.

74 BCBS Basel III: A global regulatory framework for more resilient banks and banking systems June 2011, pp. 5, 7.

75 Perry Mehrling; Zoltan Pozsar; James Sweeney; Daniel H Neilson "Bagehot was a Shadow Banker: Shadow Banking, Central Banking, and the Future of Global Finance" op. cit. pp. 10-17. 
institutions. ${ }^{7}$ The rules that regulate the dealer banks' relationship with central banks emphasize the dealer banks' duties (e.g. duty to participate in auctions, and duty to behave as a 'responsible counterparty'77) but it is actually a relationship of privilege, ${ }^{78}$ with first-hand access to the central bank. The duty to furnish relevant market information to help the central bank implement policy provides an invaluable opportunity to share their concerns and viewpoints, and establish a relationship of trust. ${ }^{79}$ Since auctioning of government debt also tends to be subject to a dealer system, ${ }^{80}$ major dealer banks enjoy a preponderant presence in the two markets that determine the primary supply of money assets.

Normally such privileges should come in a 'package' with enhanced duties, including prudential rules. ${ }^{81}$ In the market-based credit system (with dealers at its core) liquidity and certainty over prices matter the most ${ }^{82}$ which also means that market liquidity is more subject to drastic swings, hence the need of proper regulation. However, for a long time many dealer banks were not subject to the Basel prudential framework, and there are precedents showing that attempts to craft specific prudential rules for them did not generally prove effective. ${ }^{83}$

76 In the United States, the Federal Reserve Bank of New York (which implements the policies of the Federal Reserve System) interacts with a short list of (around 20) institutions. See http://www.newyorkfed.org/aboutthefed/fedpoint/fed27.html. A similar approach is adopted by the Brazil Central Bank, Bank of Canada, Honk Kong Monetary Authority (HKMA), Reserve Bank of India (RBI), Monetary Authority of Singapore (MAS), or Central Bank for the Republic of Turkey (CBRT). The People's Bank of China (PBOC) has a longer list of dealers, but they do not exceed 40. See EU Commission Study on exemptions for third-country central banks and other entities under the Market Abuse Regulation and the Markets in Financial Instruments Regulation MARKT/2014/069/G3/ST/OP June 2015.

77 Federal Reserve of New York "Administration of Relationships with Primary Dealers" January 11, 2010. http://www.newyorkfed.org/markets/pridealers_policies.html.

78 Committee on Payment and Settlement Systems (CPSS) The role of central bank money in payment systems, August 2003, p. 27.

79 The $\mathrm{PBoC}$ is perhaps the institution that most openly admits such privileged access. See www.pbc.gov.cn/rhwg/970402 f.htm.

80 Marco Arnone; George Iden "Primary Dealers in Government Securities. Policy Issues and Selected Countries Experience" IMF Working Paper WP/03/45 (March 2003). The US government uses the same primary dealers of the Federal Reserve for auctions of government debt. See https://www.newyorkfed.org/markets/pridealers_current.html

81 CPSS The role of central bank money in payment systems, August 2003, p. 27.

82 Perry Mehrling; Zoltan Pozsar; James Sweeney; Daniel H Neilson "Bagehot was a Shadow Banker: Shadow Banking, Central Banking, and the Future of Global Finance" cit. p. 17.

83 US SEC Office of Inspector General. SEC's Oversight of Bear Stearns and Related Entities: the Consolidated Supervised Entity Programme, Report No. 446-A September $25,2008$. 
In summary, the loss of control over credit creation is not a result of unconventional activities developing at the margins, but a direct consequence of the institutional structure at the system's core. ${ }^{84}$ The increased demand for liquidity was satisfied by using government bonds as 'money-like' assets, ${ }^{85}$ then, by expanding the range of these assets further, to include securitized assets, then, by re-hypothecating all available assets, ${ }^{86}$ and all this could be accomplished thanks to dealers' ability to straddle money and capital markets.

Furthermore, repo, the transaction that made all this possible, is also partly a result of policy choices. In the United States, for example, when courts challenged the status of repo contracts, and subjected them to an automatic stay in bankruptcy, ${ }^{87}$ the reaction was to enact a specific safe-harbor to protect the collateral-taker rights in bankruptcy. ${ }^{88} \mathrm{EU}$ rules provide a similar 'regulatory privilege', or subsidy, without having introduced any regulatory requirements (which could grant some degree of control) as a precondition to enjoy that privilege. ${ }^{89}$ The United States repo market is dominated by bilateral repos and tri-party repos, ${ }^{90}$ whereas in Europe market counterparties tend to use anon-

84 Some authors, such as Pozsar, also venture an explanation for the rise of shadow banking money-like assets in the preference of 'institutional cash pools' to hoard cash-like assets. Institutional cash pools include (1) the "liquidity tranche" of foreign exchange (FX) reserves (e.g. of foreign central banks), (2) the cash balance of global corporations, increasingly managed at a centralized level, (3) the centrally managed cash balances of institutional investors and large asset managers, (4) or the cash collateral reinvestment accounts of securities lenders. See Zoltan Pozsar "Shadow Banking: The Money View" op. cit. p. 24.

85 Due to their sheer size, for example, institutional cash pools could not use 'conventional' money (M0, M1, M2) assets. Coins and notes are too costly to handle in such big amounts; they have no account at central banks (only banks do), and the amounts managed by them would greatly exceed the limits of insured deposits. Zoltan Pozsar "Institutional Cash Pools and the Triffin Dilemma of the U.S. Banking System" IMF Working Paper WP/11/190 (2011), pp. 1-7. See also Robin Greenwood; Samuel Manson; Jeremy Stein “A Comparative Advantage Approach to Government Debt Maturity" Harvard Business School Working Paper No.11-035.

86 See Ricardo Caballero "The Shortage of Safe Assets. Macroeconomic Policy Implications" Presentation at the Bank of England May 2013. "On the Macroeconomics of Asset Shortages” NBER Working Paper no. 12753, December 2006, available at http:// www.nber.org/papers/w12753, and, with Emmanuel Farhi, "A Model of the Safe Asset Mechanism (SAM): Safety Traps and Economic Policy” NBER Working Paper 18737 January 2013, available at http://www.nber.org/papers/w18737. Gorton and Ordoñez have made the latest advances on the issue of privately-produced safe assets. See Gary Gorton; Guillermo Ordóñez "Collateral Crises” American Economic Review Vol. 104 (2) (2014) pp. 343-378.

87 In re Lombard-Wall Inc. v. Bankers Trust Co., 23 B.R. 165 (Bankr. S.D.N.Y. 1982)

88 Bankruptcy Amendments and Federal Judgeship Act 1984.

89 Directive 2002/47/EC on Financial Collateral Arrangements, especially its article 4.

90 Adam Copeland; Antoine Martin; Michael Walker “The Tri-Party Repo Market before 
ymous trading through CCPs, but the bilateral market remains important; all this despite bilateral repo markets tend to be less unstable. ${ }^{91}$ Until the crisis not much thought was given to the optimal structure for the market, and it is surprising how little consideration it has received since. ${ }^{92}$

Therefore, shadow banking's 'monetization' angle, the market structure that emerges from it, and the macroprudential risks associated to that structure, cannot be explained by an unidimensional tale of market players' who attempt to circumvent the rules. The story has a more complex and interwoven narrative, where policymakers made certain choices, and put some tools at market players' disposal without properly thinking through the consequences of market players' use of these tools. The answer to the question of 'what is money', thus, transcends Metallist and Chartalist versions: ${ }^{93}$ modern money and money markets are the combined result of a process of decentralization of money creation led by market players who nonetheless still use government-backed assets (central bank reserves and government bonds) and legal institutions as the building blocks of that process. The result is a cause of concern, but public authorities are partly to blame by providing the tools without an instructions manual, or at least some guidelines and controls.

\section{Shadow Banking: A Critical Appraisal of Reforms}

The previous Section showed how official accounts of shadow banking fail to capture the complex relationship that exists between market forces and their institutional environment, both with respect to shadow banking entities (GSEs, MMFs, dealer banks) or transactions (securitization or repos). This Section tries to evaluate how these biases can affect proposals of reform, on shadow banking intermediation (1) and money markets (2); as well as more general reforms on Banking and Capital Markets Union (3).

\section{Intermediation reforms. Shadow banking, legal interpretation and consis- tency}

There are two ways of approaching shadow banking as an 'intermediation' problem: we can consider it a 'borderline' problem (where there is disagree-

the 2010 Reforms” Federal Reserve Bank of New York Staff Report no. 477 November 2010.

91 Loriano Mancini; Angelo Ranaldo; Jan Wrampelmeyer "The Euro Interbank Repo Market" op. cit.

92 The exception is the task force for the tri-party repo market infrastructure reform. See

93 Supra II.1. 
ment as to how to apply the rules to a case, but agreement as to the rules' underpinning principles), or a pivotal problem (where the disagreement about the application to a case masks a deeper disagreement about the principles). ${ }^{94}$

If we consider it a borderline problem, the question would be 'how can we apply bank-like prudential rules to non-banks?' This is what the FSB has proposed in its document on 'shadow banking entities'. The FSB classifies shadow banks by their 'functions', which are a measure of their risk, ${ }^{95}$ and proposes a policy toolkit for each function. This toolkit consists in applying to non-banks the prudential rules of banks with varying degrees of intensity, including the 'core' prudential rules (on leverage, capital or liquidity requirements ${ }^{96}$ ) and other more specific rules depending on the entities' specific risks. ${ }^{97}$ The FSB supplements this by a peer review process where it will assess how the different jurisdictions comply with this approach. ${ }^{98}$

94 The distinction between "borderline" and "pivotal" cases is a centerpiece of Dworkin's approach to legal interpretation. See Ronald Dworkin Law's Empire Oxford, Hart Publishing, 1998, p. 41.

95 The five "functions" are (1) Management of collective investment vehicles11 with features that make them susceptible to runs; (2) Loan provision that is dependent on shortterm funding; (3) Intermediation of market activities that is dependent on short-term funding or on secured funding of client assets; (4) Facilitation of credit creation; (5) Securitisation-based credit intermediation and funding of financial entities. FSB Strengthening Oversight and Regulation of Shadow Banking Policy Framework for Strengthening Oversight and Regulation of Shadow Banking Entities 29 August 2013, pp. 6-10. An alert reader will have no difficulty in identifying the functions undertaken by (1) MMFs, (2) finance companies, (3) broker-dealers and some hedge funds, (4) insurance companies and some hedge funds, (5) complex securitization vehicles.

96 For three of the banking "functions" ("provision of loans that is dependent on short-term funding", "Intermediation of market activities that is dependent on short-term funding or on secured funding of client assets", "facilitation of credit creation") the FSB proposes similar solutions, consisting in the adoption of bank-like prudential requirements, such as capital and liquidity requirements, which are also present in the proposals for fund management susceptible to runs, and securitization-based credit intermediation. See FSB Strengthening Oversight and Regulation of Shadow Banking Policy Framework for Strengthening Oversight and Regulation of Shadow Banking Entities 29 August 2013, pp. 17-21.

97 E.g. rules limiting redemptions for fund management susceptible to bank-like runs, restrictions on assets/collateral for this activity and for securitization-based intermediation, restrictions on the use of clients' assets for intermediation of market activities that is dependent on short-term funding or on secured funding of client assets, or enhanced risk management practices to capture tail events. FSB Strengthening Oversight and Regulation of Shadow Banking Policy Framework for Strengthening Oversight and Regulation of Shadow Banking Entities 29 August 2013, pp. 17-21.

98 FSB Thematic peer review on the implementation of the FSB policy framework for other shadow banking entities Summarized Terms of Reference, 22 July 2015, available 
An approach that treats the problem as pivotal, however, would begin by seeing asking 'what is a bank?' More specifically, it would try to examine the reason to distinguish a bank from other types of entities in the law, not only in economic literature. In this regard, what matters is not the 'bank' concept, ${ }^{99}$ but the rationale behind its regulation, and the way this rationale is actually reflected in the rules. According to these rules, a 'credit institution' is:

"an undertaking whose business is to receive deposits or other repayable funds from the public and to grant credits for its own account; $" 100$

Thus, the rules define the institution by its function (i.e. not its legal form, or the 'charter' it chooses). This can be surprising to someone who is used to the idea that the recipe for shadow banking is more 'functional' regulation. ${ }^{101}$ How can one square this with the fact that the regulation was already functional before the crisis? ${ }^{102}$ As it stands, the definition above could encompass most new types of financial intermediation. It all depends on how far one is prepared to stretch concepts such as "receiving deposits or other repayable funds", "from the public", or "granting credits". Furthermore, in Romanelli the Court of Justice of the European Union (CJEU) showed that it was prepared to stretch these concepts quite far. In that case, the Romanelli brothers were prosecuted for selling to third parties instruments representing an

at http://www.financialstabilityboard.org/wp-content/uploads/TOR-for-peer-reviewon-shadow-banking-summarized-29062015-final.pdf

99 Concepts by themselves, however, tell us little about the efficiency or fairness of the result achieved, and disconnect the legal exercise from the real conflicts of policy. Legal formalism or Begriffjurisprudenz are well-known attempts to justify the consistency of the legal system on the basis of concepts; but were largely discredited because there is no "heaven of concepts" that can be reached through logical deduction. H.L.A. Hart "Jhering's Heaven of Concepts and Modern Analytical Jurisprudence" reprinted in Essays in Jurisprudence and Philosophy Oxford University Press, 1983, pp. 265-278.

100 Article 4 (1) (1) Regulation 575/2013.

101 FSB Strengthening Oversight and Regulation of Shadow Banking. Policy Framework for Strengthening Oversight and Regulation of Shadow Banking Entities 29 August 2013 p. 19. See also Steven L Schwarcz "Regulating Shadow Banking" Review of Banking and Financial Law Vol. 31 (2011-2012) p. 639.

102 And, in case of doubt, the norm's recitals indicate that The scope of measures should therefore be as broad as possible, covering all institutions whose business is to receive repayable funds from the public, whether in the form of deposits or in other forms such as the continuing issue of bonds and other comparable securities and to grant credits for their own account. Recital (14) Directive 2013/36/EU, on access to the activity of credit institutions and the prudential supervision of credit institutions and investment firms. The reference comes from the First Council Directive 77/780/EEC of 12 December 1977 on the coordination of the laws, regulations and administrative provisions relating to the taking up and pursuit of the business of credit institutions. 
amount receivable and immediate repurchased at a price which incorporated the agreed interest, and warrants representing an option to acquire debentures issued by Romanelli Finanzaria SpA. ${ }^{103}$ The Court had to decide whether this amounted to 'banking'. It held that it did, and thus a license was needed, because the definition had to be interpreted "broadly" ${ }^{104}$ Thus, if the approach of the rules is functional, and the courts are prepared to interpret it with flexibility, where is the problem?

The problem, as usual, is in the details. It is one thing for the rules to be interpreted functionally and broadly in a case where the alternative is that the activities go unregulated. It is another to ask that the same functional and broad interpretation should be done in cases where the activity is already regulated by a different set of rules. This is easy to see if we switch from the rules for credit institutions to the rules for other intermediaries. An "investment firm" is defined as "any legal person whose regular occupation is the provision of one or more investment services [...] on a professional basis", including reception, transmission and execution of orders, dealing on own account, portfolio management or investment advice ${ }^{105}$ (a broad and functional definition). An undertaking for the collective investment in securities (UCITS) is an undertaking that invests in transferable securities or other financial assets, raises capital from the public, and functions on the principle of risk-spreading, with units that are redeemable by investors ${ }^{106}$ (same approach). And an "alternative investment fund (AIFs)" (which includes hedge funds) is a UCITS with an investment policy, but one that does not need

103 Case C-366/97 Criminal proceedings against Massimo Romanelli and Paolo Romanelli ECR [1999] I-00855 at 5. According to Italian banking regulations that had transposed the Directive, the term "repayable funds" could be interpreted either as referring only to financial instruments which, by their intrinsic nature, embody an obligation of repayment, or as covering also those financial instruments in which the requirement of restitution derived from specific contractual provisions. Romanelli para. 7. The Romanelli brothers defense was that the funds raised from the public through certain financial instruments were not "intrinsically repayable", but repayable only as a result of a separate "restitution agreement". The result ultimately depended on the interpretation given to the Directive's provision.

104 The Court stated, referring to the Opinion of AG Fennelly, 29 October 1998, that " $a$ narrower interpretation, as contended for by the defendants in the main proceedings, would undermine the objective of protecting consumers against the harm which they could suffer through financial transactions." Ibid at 16.

105 Article 4 (1) of the MiFiD II (Directive 2014/65/EU) defines "investment firm" as an undertaking providing investment services and activities over financial instruments, and refers to Annex I for a specification of what are "investment services" (Section A) and what are "financial instruments" (Section C).

106 Article 1 (2) Directive 2009/65/EC of 13 July, on the coordination of laws, regulations and administrative provisions relating to undertakings for collective investment in transferable securities (UCITS). 
authorization as a UCITS (normally because the number of investors is below the legal requirement ${ }^{107}$ ). Insurance undertakings are also characterized in seemingly broad terms. ${ }^{108}$

Thus, considered in isolation, all the rules adopt a functional and broad approach, which ensures that financial activities do not go unregulated; but the combination of these same rules can create a conceptual overlap for entities engaging in new activities, ${ }^{109}$ an overlap that can be exploited by their sponsors to avoid the more burdensome (usually banking) rules, using other rules as a safe harbor. The shadow banking problem does not arise in a scenario of unregulated activities, but differently regulated ones. In this scenario, proposing a 'functional' approach for banking prudential rules is tantamount to advocating that these rules should be treated as a kind of 'trumping card', with preference over the rest, or as an interpretative device to construe other rules in light of their meaning and purpose.

This 'trumping' or interpretative approach would require to consider the universe of the rules for the different types of financial institutions as a whole body, inspired by the same principles, and extract from that body that prudential principles, as reflected in bank rules, are the prevailing principles, a sort of 'core', or 'model' legal propositions, which irradiate or inspire other rules. ${ }^{110}$ This is a complex task, ${ }^{111}$ and it is made more difficult by the fact that prudential goals, albeit present from long ago in the economic discourse, are relatively recent tools of legal interpretation. Consider again the Romanelli case, where the CJEU held that a 'broad' interpretation of banking activities was appropriate. The Court justified this view on consumer protection, which, in the Court's own assessment, was the principle underpinning the rules. ${ }^{1{ }^{12}}$ This view is still very present in the scope of rules applicable to financial intermediaries when they require that these intermediaries take, or manage,

107 Article 4 (1) (a) of Directive 2011/61/EU on Alternative Fund Managers.

108 See Directive 2009/138/EC (Solvency II), Annex I A, nos. 14-15.

109 See David Ramos Muñoz "Living on the Edge: Securitization Supervision and Characterization Problems” European Company Law Review Vol. 6 Issue 5 (2009) pp. 217227.

110 This would be consistent with Dworkin's 'law as integrity' approach. See Ronald Dworkin Law's Empire Oxford, Hart Publishing, 1998.

111 Dworkin's 'ideal' judge who performs this task is called 'Hercules'. Other judges can only aspire to replicate Hercules' method in an imperfect form. See Ronald Dworkin Law's Empire cit.

112 The Court held that. "the banking sector is a particularly sensitive area from the point of view of consumer protection. Consumers must be protected against the harm which they could suffer through banking transactions effected by credit institutions disregarding the requirements relating to their solvency or whose managers do not have the necessary professional qualifications or integrity". Ibid at 11, with reference to Case C-222/95 Parodiv Banque H. Albert de Bary [1997] ECR I-3899. 
funds "from the public". ${ }^{113}$ Yet consumer protection as a principle does not justify extending banking rules to cases that could be covered by other rules, nor interpreting the rules for other intermediaries in light of banking rules. Even an understanding that sees microprudential rules as a means to anticipate consumer protection, does not per se justify a teleological extension of banking rules, or their meaning.

It is possible to realize now the nature of shadow banking's problem. The problem is with the definition of 'bank', because this definition, and the scope of application of the rules, can differ depending on whether the aim of the rules is to protect 'consumers', or also to protect the 'system'. Arguably, the substance, and emphasis of bank rules has lately pivoted towards the system, ${ }^{114}$ but this is the result of recent reforms, and has yet to translate into a switch of the interpretative approach for all the rules. This task is made more difficult by three factors. One is the difficulty to read such clear prudential 'meaning', or priority, in some sets of rules. The AIF Directive, for example, was passed amidst fears about the risk hedge funds could pose to the market, ${ }^{115}$ but the rules themselves are at least as focused on transparency and client protection, or the fate of the companies where funds take a controlling stake, as they are on leverage, liquidity, or risk management. ${ }^{116}$ Furthermore, rules that reflect prudential concerns are often not policed by supervisors specialized in prudential rules (e.g. central banks), but by supervisors specialized in market conduct rules (e.g. securities commissions ${ }^{117}$ ).

A second factor is that, generally, the scope of application of the rules (even prudential rules) relies more on the external perception of the service (which may be a relevant factor from a consumer protection perspective), than its intrinsic risk (which would be the relevant factor from a prudential perspec-

113 See, e.g. article 4 (1) (1) CRR; article 1 (2) (a) UCITS Directive.

114 Regulation 575/2013 (Capital Requirements Regulation, or 'CRR') uses the word 'systemic' 32 times, and Directive 2013/36/EU (Capital Requirements Directive, or 'CRD') 108 times. The forerunner of the two texts, Directive 2006/48/EC, used the word once, to refer to the systemic importance of some institutions when making a supervisory review. The word 'macroprudential' is used 40 times in CRR, and 14 times in CRD, for 2006/48/EC Directive's none. Furthermore, articles 133-136 CRD introduce systemic risk buffers and countercyclical buffers as prudential tools.

115 See, e.g. recitals (17), (49), (63), (69), (79), etc of Directive 2011/61/EU of 8 June 2011 on Alternative Investment Fund Managers, which all make reference to 'systemic risk'.

116 Article 25 focuses on leveraged AIFs, and articles 15 and 16 focus on risk and liquidity management, but articles 12 (general principles) is clearly inspired by a 'fiduciary', or 'principal-agent' approach, which is supplemented by article 14 (conflicts of interest),21 (depositary), or 22-23 (transparency), while the concern of articles 26-30 is the well-being of companies where AIFs take a controlling stake.

117 See, e.g. articles 45 et seq. AIF Directive, or articles 40 et seq. of MMF regulation proposal, which also attribute powers to ESMA. 
tive). One only needs to look at the definitions four paragraphs above to realize that. This is consistent with a construction of the rules that has consumer protection at its core, rather than more 'prudential' principles, such as the need to restrict leverage, or to preserve liquidity, but it does not look well for our purposes to seek the consistency of prudential rules.

In fact, historical precedents show that the norm has been that even rules inspired by prudential concerns follow consumer-based distinctions in their scope of application. In the post-Glass-Steagall era, the United States Supreme Court had to decide, in several landmark cases, whether certain acts breached the prohibition of the Act. The debate always revolved around whether the 'services' offered were 'banking' or 'investment', not whether the entity had one, or another, risk profile. ${ }^{118}$ The same can be said about the banking-insurance distinction. ${ }^{119}$ In fact, the emphasis on 'functional' regulation is often based on consumer protection considerations, not prudential ones. ${ }^{120}$ In the EU, a proposal of a regulation on Money Market Funds (MMFs) was inspired

118 In Investment Company Institute v. Camp, 401 U.S. 617 (1970), the US Supreme Court held that an authorization by the Office of the Comptroller of the Currency (OCC) to a commercial bank to sell investment funds was invalid. In 1972, the Board of Governors of the Federal Reserve amended its Regulation Y (which developed Section 4 (c) (8) of the Bank Holding Company Act, and permitted bank holding companies and their nonbanking subsidiaries to act as an investment advisers to a closed-end investment company. Section 16 of the Banking Act of 1933 (Glass-Steagall Act) prohibited a bank from "underwriting" or purchasing securities, while $\$ 21$ conversely prohibited firms "engaged in the business of issuing, underwriting, selling, or distributing" securities from engaging in banking. In Board of Governors v. Investment Company Institute, 450 U.S. 46 (1981). The US Supreme Court held that Regulation Y did not violate the Act because (1) the modification Regulation Y was in accordance with "normal" banking practice; and (2) the Glass-Steagall Act did not intend to limit the Board's discretion. Ibid at. 25. The same criterion was reiterated in Securities Industry Association v. Board of Governors, 468 U.S. 207 (1984); and in Nationsbank of N.C v Variable Annuity Life Insurance Co. 513 U.S. 251 (1995). In all these cases the focus was on the activity, and the Board's discretion to evaluate it, not on the risk resulting from the bank undertaking that activity.

119 See, for example, Saxon v. Georgia Ass ' $n$ of Independent Insurance Agents 399 F.2 d. 1010 (5th Cir. 1968); Chevron U.S.A., Inc. v National Resources Defense Council, Inc 467 U.S. 837 (1984); Variable Annuity Life Co. v. Clarke, 998 F.2 d 1295 (5th Cir. 1993); NationsBank v. Variable Annuity Life Ins. Co., 513 U.S. 251 (1995). The problem was never whether insurance companies incurred risks typical of banking, meaning that they should be made subject to banking regulation.

120 Melanie L. Fein, "Functional Regulation: A Concept for Glass-Steagall Reform, Stanford Journal of Law Business \& Finance Vol. 2 (1995); J. Virgil Mattingly \& Kieran J. Fallon "Understanding the Issues Raised by Financial Modernization" Vol. 2 N.C. Banking Inst. Vol. 25 (1998). 
by prudential concerns, ${ }^{121}$ but its rules stated that "No collective investment undertaking shall be established, marketed or managed in the Union as MMF“, i.e. the proposed rules assumed that a sponsor would be willing to establish, market, or manage the fund, as an MMF, as a trigger for the rules, ${ }^{122}$ rather than the fund's risk structure.

A third factor is the difficulty of public authorities to resist the temptation to carve-out exceptions to the general rules for specific types of institutions that perform a socially desirable role. The above difficulties in finding common prudential principles in harmonized EU rules together pales in comparison with the task of making sense of domestic rules, which may reflect specific political compromises. ${ }^{123} \mathrm{GSEs}$, saving banks, finance companies are but the tip of the iceberg of shadow banking's idiosyncratic nature. The FSB seems to be aware of this, and in its shadow banking monitoring reports, together with aggregate data, it now offers individual case studies, ${ }^{124}$ but that has not made it change its overall approach.

Thus, shadow banking is, at its core, a problem of legal consistency. Legal consistency is eroded when market players seek to avoid the spirit of the rules; but, even more, when lawmakers grant carve-outs to those rules, or different rules. Consistency is also eroded when rules that reflect the same principles are scattered across different legal texts. This is especially acute when the legal norms have a scope of application inspired by principles that differ from the

121 Proposal for a Regulation on Money Market Funds (MMFs) Brussels, 4. 9. 2013 COM (2013) 615 final 2013/0306 (COD) (hereafter: MMF regulation proposal). Recitals (8), (28) or article 45 explicitly reflect prudential concerns. The context of the proposal illustrates the concern over the risk of "runs". MMF regulation proposal pp. 2-3.

122 The rules' scope of application was defined in functional terms, however. Article 1 MMF regulation proposal stated that it would apply to undertakings that need authorization under the UCITS Directive or AIFM Directive, and "invest in short term assets and have as distinct or cumulative objectives offering returns in line with money market rates or preserving the value of the investment."

123 It is useful to focus on the disparate figures for Other Financial Intermediaries (OFIs) offered by the FSB, each of which tells a different story. See FSB Global Shadow Banking Monitoring Report 2015, 12 November 2015.

124 See, e.g. FSB Global Shadow Banking Monitoring Report 2015, 12 November 2015, whose Annex 2 p. 48 focuses on Ireland, or the 2014 report, 30 October 2014, where Annex 2, p. 30 focused on Switzerland. The FSB 2015 report indicates that the dominant class of Irish shadow banks are 'investment funds' ( $€$ 1,634 billion at end-2014), and that the majority of their managers are located outside Ireland. The Irish central bank supervises funds, and foreign authorities their managers. Ibid p. 50. Yet the report does not delve more deeply on what supervisory arrangements are in place. Nor does it describe the institutional choices (tax and regulatory) that led to the present state, which would be a good measure to calibrate the difficulty of future reforms. A similar thing can be said of Financial Vehicle Corporation (FVCs). Ibid at 51. 
principles behind the substantive rules in the body of the norm, or when that body mixes prudential and consumer protection rules. Given the nature of the problem, enacting new rules for each new type of institution or activity, as it seems to be suggested by the FSB, ${ }^{125}$ or the European Commission, ${ }^{126}$ will only exacerbate the problem of inconsistency and will make a principles-based interpretation more difficult.

The only sensible solution in light of the above diagnosis would be to enhance consistency, by merging the rules inspired by common prudential principles, and re-defining their scope of application in terms of the risks of the activity (or the asset/liability structure as a proxy for that risk ${ }^{127}$ ) not the external perception of that activity. This would result in a Prudential Directive/Regulation, applicable to all 'financial intermediaries'. In fact, this view finds support in the 'twin peaks' structure, which proposes to concentrate prudential supervision into one entity; ${ }^{128}$ or in the attempt by the EU legislature to create a 'Single Prudential Rulebook' applicable to banks and investment firms. ${ }^{129}$ The problem of these initiatives is not their intuition, which is right, but their

125 The FSB is not explicitly suggesting new statutes, but, in the 'fourth overarching principle' of its peer review process, it states: "that authorities should assess their non-bank financial entities based on the economic functions and take necessary actions drawing on tools from their policy toolkit if necessary to mitigate the financial stability risks identified." FSB Thematic peer review on the implementation of the FSB policy framework for other shadow banking entities Summarized Terms of Reference 22 July 2015 , p. 4. Thus, authorities will be rewarded for undertaking new actions, especially if they draw from the policy toolkit drawn by the FSB.

126 The European Commission Communication from the Commission to the Council and the European Parliament Shadow Banking - Addressing New Sources of Risk in the Financial Sector Brussels, 4. 9.2013 COM (2013) 614 final was accompanied by a new proposal for a regulation on money market funds (MMFs). See http://ec.europa.eu/ finance/general-policy/shadow-banking/index_en.htm\#maincontentSec3

127 "The fault line of regulation should be primarily determined by the institution's actions and asset-liability structure, while its legal identity as bank, insurance company, SIVetc. should only play a secondary role." The Fundamental Principles of Financial Regulation Geneva Report on the World Economy 11 January 6, 2009, p. 26.

128 Michael Taylor, “Twin Peaks”: A Regulatory Structure for the New Century Centre for the Study of Financial Innovation (1995). This approach has been followed after the crisis by reforms in the United Kingdom or France. See Financial Services Bill 2012 (see also Andrew Bailey “The Prudential Regulation Authority” Bank of England Quarterly Bulletin (2012) Q4, pp. 354-362); French Ordinance number 2010-76.

129 The core of the 'Single Rulebook' are the common prudential requirements set forth in CRD and CRR, plus the Directive 2014/59/EU of the European Parliament and of the Council of 15 May 2014 establishing a framework for the recovery and resolution of credit institutions and investment firms (Bank Recovery and Resolution Directive, or BRRD), and Directive 2014/49/EU of the European Parliament and of the Council of 16 April 2014 on deposit guarantee schemes. The European Banking Authority (EBA) has been entrusted with developing the Single Prudential Rulebook. See https:// 
reach, which is not ambitious enough. An institutional perspective, based on precedents, and legal construction, shows that arbitrage festers among complex, scattered, and disparate rules. The only possible conclusion is that a unification of prudential rules for all financial intermediaries would go a long way towards solving the problem.

Some reasonable criticism can be anticipated. One could say that most financial intermediaries would be out of business if they were subject to Basel-like prudential rules. The answer is that exceptions could be made, for example requiring simplified, or less exacting, prudential requirements for entities below a certain size, entities with a better matching of maturities between assets and liabilities, or entities that perform certain socially desirable functions. However, these exceptions should be included into the prudential requirements, not granted via separate statutory rules. This would achieve three extra goals. One, an exception that is codified as a statutory exemption is an express acknowledgement that, despite a certain entity engages in 'credit intermediation' or 'maturity transformation', lawmakers choose to grant it different conditions. This is a more open and transparent way of doing policy than granting better deals behind closed doors, and then pretending that the entity is 'distinct', or that the entity does not do 'banking' or 'financial intermediation'. Two, in the process of devising exceptions or special rules for other intermediaries, policymakers may inevitably realize that bank rules are, themselves, unnecessarily complicated, and choose to make them more manageable. ${ }^{130}$ Three, by acknowledging that financial intermediaries may do different things, yet pose risks of similar nature, the consistency of the whole edifice of rules will be strengthened, not weakened, and the questions 'what is a bank' and 'why is it regulated' will find a more complete, and holistic, answer.

This is not to say that implementing such reforms would be easy. In fact, given their difficulty, and the it is unlikely. Yet a proper approach to the problem of shadow banking intermediation should begin by admitting where the problem lies, and adequately acknowledging its legal dimension. Principles of legal construction should play a defining role of policy if reforms are to achieve

www.eba.europa.eu/regulation-and-policy/single-rulebook/interactive-single-rulebook

130 Some authors are already advocating for a necessary simplification of Basel rules. See Andrew Haldane; Vasileios Maduros "The dog and the Frisbee" Speech delivered at the Federal Reserve Bank of Kansas City's 36th economic policy symposium The Changing Policy Landscape Jackson Hole 31 Aug 2012. See also Marcelo Madureira Prates "Why Prudential Regulation Will Fail to Prevent Financial Crises. A Legal Approach" Banco central do Brasil Working Papers, 335, Nov. 2013. One does not need to share the authors' conclusions to accept that bank prudential rules have become too complicated and unmanageable. 
anything. Otherwise, new rules will only lead to more fragmentation, arbitrage, and subsidies.

\section{Money market reforms. Institutional, monetary and constitutional impli- cations}

It is noticeable how, once one moves to the perspective of 'monetization' and money markets, policymakers become much more cautious. Unlike the 'intermediation' field, where the problem is deciding how far to go, in the monetization field the debate is about what the problem is. Still, even by those standards, the proposed shadow banking reforms are surprisingly timid.

To be fair, the reform proposed by the European Commission on Securities Financing Transactions (SFTs) has correctly identified the need to address the data gap as a priority, and thus focuses on reporting duties (to facilitate information gathering by the supervisor) and disclosure duties (to enhance investor protection). ${ }^{131}$ This is in line with the FSB framework on repos and securities lending, which primarily focuses on transparency and data-gathering. ${ }^{132}$

The FSB goes a bit further, and proposes standards for collateral valuation and management, ${ }^{133}$ and cash collateral reinvestment, to address liquidity risks, ${ }^{134}$

131 The European Commission proposal is divided into "Transparency of SFTs including registration and supervision of trade repositories" (Chapters II and III), and "Transparency towards investor" (Chapter IV).

132 Of the FSB's 11 recommendations, the first 3 focus on the need to gather better, more granular, and more specific data on these markets, and at least 2 others focus on the need to increase transparency of financial intermediaries towards the public and their clients. Recommendation 1 focuses on the need that authorities collect more granular data on securities lending and repo exposures amongst large international financial institutions; recommendation 2 emphasizes the need that data collection includes trade-level (flow) data and regular snapshots of outstanding balances (position/stock data) for repo markets, and at least regular snapshots of outstanding balances for securities lending; and recommendation 3 indicates that the FSB should aggregate the national/regional data. Recommendations 4 and 5 state the need to improve public disclosure for financial institutions' securities lending, repo and wider collateral management activities, and consider existing gaps in existing reporting requirements. Recommendation 7 also states that new rules regulating re-hypothecation ensure that intermediaries' clients are sufficiently informed. See FSB Strengthening Oversight and Regulation of Shadow Banking. Policy Framework for Addressing Shadow Banking Risks in Securities Lending and Repos 29 August 2013 pp.6-12, 15, Annex 1, pp. 20-21.

133 Ibid p. 17 (recommendation 9).

134 Ibid pp.12-15 (recommendation 6). The new regime should ensure that the objective is capital preservation, and that the management of cash collateral does not add extra risk, by looking in particular at the risk of maturity mismatch. To address these goals the 
as well as mandatory rules for the calculation of haircuts for non-centrally cleared repos, which try to limit procyclicality. ${ }^{135}$

However, these measures fail to address the institutional aspects that were (and are) at the root of money markets' shadow banking problem. For example, regarding asset re-hypothecation, the FSB's approach relies on disclosure and client consent, rather than regulatory limits, ${ }^{136}$ which, again, shows the tension between (macro) prudential and consumer/investor protection principles as the rationale behind the rules. Regarding a possible derogation or restriction of repo's bankruptcy protection (regulatory subsidy), the FSB recommends inaction. ${ }^{137}$ The FSB also recommends inaction with regard to the possibility of mandating, or encouraging, centralization of trades onto CCPs, despite centralization has been the approach for OTC derivatives, ${ }^{138}$ and evidence suggests that the CCP-centralized repo market is more stable. ${ }^{139}$ Furthermore, neither the FSB nor the Commission mention how the processes and dynamics of money and credit growth can be stabilized in the absence of restrictions, or centralized controls.

Thus, the more intrusive measures, which consist in 'codifying' a list of liquid assets, or limiting cash collateral reinvestment, will be insufficient. It is unrealistic to assume that the range of money assets can be determined by regulatory diktat, without further measures that influence the market's institutional structure.

The nature of those measures will depend on the view one adopts about the causes of current money-creation processes. One could adopt a 'restrictive' view, which surmises that current money creation results from speculative flows; or a more 'skeptical' view, which considers that it may result from

specific rules would require that certain percentages are invested in deposits or government debt, or would impose caps on the average maturity of the portfolio, and maximum maturity of the instruments.

135 FSB Regulatory framework for haircuts on non-centrally cleared securities financing transactions October 2014

136 This includes a broad recommendation that an expert group examines harmonization of client asset protection rules, and more concrete proposals of de minimis limits to rehypothecation, such as its restriction to entities subject to liquidity risk rules, or the prohibition that re-hypothecation is used to finance the own accounts activities of the intermediary (recommendations 7 and 8). See FSB Strengthening Oversight and Regulation of Shadow Banking. Policy Framework for Addressing Shadow Banking Risks in Securities Lending and Repos cit. p. 16.

137 Ibid pp. 18-19 (recommendations 10-11).

138 Regulation (EU) No.648/2012 of the European Parliament and of the Council of 4 July 2012 on OTC derivatives, central counterparties and trade repositories.

139 Loriano Mancini; Angelo Ranaldo; Jan Wrampelmeyer "The Euro Interbank Repo Market" Swiss Finance Institute Research Paper No. 13-71 July 30, 2015. 
speculation, but it may as well not. This is important, as either view calls for a different approach.

A restrictive view would require the list of 'liquid' money assets to be accompanied by rules that constrain speculative flows. Some authors suggest that this could be accomplished by capital controls, taxation of flows, or subsidiarisation and ring fencing. ${ }^{140}$ Even though some current structural reforms emphasize ring-fencing, ${ }^{141}$ the shadow banking angle is not very present.

Following the same 'restrictive' philosophy, another possibility would be to implement the $100 \%$ reserve requirement for banks, meaning that monetary and credit functions would have to be separated. ${ }^{142}$ Yet, rather than bringing shadow banking back into the regulatory perimeter, this would push all lending towards shadow banking entities; an aspect (among many) which advocates of the $100 \%$ reserve system tiptoe over. ${ }^{143}$ However, albeit unrealistic,

140 Adair Turner "Too much of the wrong sort of capital flow", Conference on Capital Account Management and Macro-Prudential Regulation for Financial Stability and Growth Centre for Advanced Financial Research and Learning, (CAFRAL)/Reserve Bank of India New Delhi, 13 January 2014.

141 In the United States, see Section 619 Dodd-Frank Wall Street Reform and Consumer Protection Act; Sec. 148(5) Financial Services (Banking Reform) Act 2013; in France, see Loi no. 2013-672 du 26 juillet 2013 de séparation et de régulation des activités bancaires, J.O. n' 173 du 27 juillet 2013; in Germany, see Gesetz zur Abschirmung von Risiken und zur Planung der Sanierung und Abwicklung von Kreditinstituten und Finanzgruppen $7 / 8 / 2013$.

142 See Irving Fisher "100\% Money and the Public Debt", Economic Forum, Spring 1936, pp.406-420; Milton Friedman "A Monetary and Fiscal Framework for Economic Stability" American Economic Review, Vol. 38, No.3 (June 1948) pp.245-264. The idea was revisited by Benes and Kumhof. See Jaromir Benes; Michael Kumhof "The Chicago Plan Revisited" IMF Working paper WP/12/202, August 2012. The idea of limited purpose banks was also briefly discussed at the beginning of the crisis (see L Kotlikoff, Jimmy Stewart is Dead: Ending the World's Ongoing Financial Plague with Limited Purpose Banking, Wiley 2010. J Kay, Narrow Banking, The Reform of Banking Regulation, CFSI, 2009).

143 For example, Benes and Kumhof propose that the 'credit function' would be undertaken by 'investment trusts', which could be funded by savers' equity, and invest in corporate equity, or lend money to net borrowers once savers had deposited government-issued money with them, in exchange for debt instruments. Jaromir Benes; Michael Kumhof "The Chicago Plan Revisited" op. cit. p. p. 5. In the second alternative, it is difficult to see how any rules could prevent these debt instruments from being treated like money-like (a problem the authors acknowledge, but do not resolve). In the first alternative, it is difficult to see how entrepreneurs and households could then have access to credit, not to mention the fact that it would be impossible to 'eliminate corporate debt' as the authors propose, unless the loan contract were declared illegal. In any event, it is unclear how the rules could prevent money and lending activities from being combined (even if the 'conglomeration' of such activities were prohibited, firms could sign strategic agreements or have implicit understandings so that credit 
this view offers a holistic approach, which considers the whole market structure and dynamics.

Under an 'open' or 'skeptical' view, the priority would be to have not a set of restrictive rules, but of flexible tools that public authorities can use to adjust supply and demand in money markets. Thus, instead of the above rules-based approach, this would mean adopting a discretion-based one. Rather than on regulatory restrictions, this would rely on public authorities' discretionary powers to stabilize supply and demand of money assets.

This role would typically fall with central banks, who would become 'dealers of last resort'. ${ }^{144}$ During 'lean' times, when deposits and other money-like assets deposits are being destroyed, central banks could expand the money supply, by expanding the range of assets that they could accept for their operations (thereby enhancing their liquidity and 'moneyness'), as the ECB did during the crisis, ${ }^{145}$ and as authors like Minsky suggested should be done. ${ }^{146}$ They could also expand the counterparties they could deal with, ${ }^{147}$ thereby enhancing the perceived liquidity of the instruments issued or traded by them. Either way, this would pose three major challenges.

The first challenge would be to understand the mutual influences between monetary policy and prudential requirements. ${ }^{148}$ Regulatory restrictions on capital and liquidity should be consistent with monetary tools (e.g. regulatory lists of 'liquid' assets should be aligned with the list of assets accepted as collateral by central banks, liquidity ratios should not push banks towards longer-term financing operations, instead of short-term ones, where central banks set their policy rates, etc ${ }^{149}$ ).

extended would be implicitly backed by government-issued money-like assets. If history offers any lessons it is about how easily ideal economic plans overlook the legal side.

144 Perry Mehrling; Zoltan Pozsar; James Sweeney; Daniel H Neilson "Bagehot was a Shadow Banker: Shadow Banking, Central Banking, and the Future of Global Finance" (December 6, 2013). See also Zoltan Pozsar "Shadow Banking: The Money View" OFR Working Paper (July 2014).

145 See, e.g. the ECB's asset-purchase programs https://www.ecb.europa.eu/mopo/implement/omt/html/index.en.html.

146 Hyman Minsky Stabilizing an Unstable Economy op. cit. pp. 354-358 (control of asset growth), 358-363 (role of central banks).

147 See http://www.newyorkfed.org/markets/rrp_counterparties.html. Last checked, 29 October 2014

148 Claudio Borio; Haibin Zhu "Capital regulation, risk-taking and monetary policy: a missing link in the transmission mechanism?” BIS Working Papers No. 268 (December 2008).

149 Speech by Lorenzo Bini Smaghi, Member of the Executive Board of the ECB "Basel III and monetary policy" at the International Banking Conference - "Matching Stability 
The second challenge would be in expanding the task of central banks, to make them intervene not only during crisis times, but also during good times, by 'leaning against the wind', when there is an excess in the growth of credit. ${ }^{150}$ This requires models that take into account the non-linearities caused by financial frictions better than the currently used Dynamic General Stochastic Equilibrium models. ${ }^{151}$ Before better models are fully functional, central banks will be extremely reluctant to intervene during boom years. This may not only affect the administration of monetary interventions, but also the application of countercyclical requirements. Given their already proven willingness to intervene in lean times, this creates an asymmetry that can give rise to an important problem of moral hazard.

The third challenge is to restore some degree of control over money-creation processes to the authorities entrusted with monetary and financial stability. Subjecting dealer banks to the same prudential rules as regular banks (as CRD/ CRR do ${ }^{152}$ ) is a good start, but that does not knock global dealers off from their pedestal. Furthermore, repo rules could be reformed to favor centralization of repo trades towards CCPs subject to regulatory requirements on haircuts and collateral, and their clearing and settlement through Central Securities Depositaries $\left(\mathrm{CSDs}^{153}\right)$, under ECB supervision.

Thus, current reforms and proposals offer some interesting openings, but clearly miss the mark over the dimension of the problem. There is no attempt to change the structure of the market, nor any mention as to how regulatory policy should be combined with central bank interventions. As far as beginnings go, it is even less promising than the one of shadow banking intermediaries.

and Performance: The Impact of New Regulations on Financial Intermediary Management", Milan, 29 September 2010, available at

150 Early proponents of this approach (at a time when Alan Greenspan's approach to 'mop up' after the asset bubble burst, was the dominant in the 'lean' versus 'clean' debate). See Claudio Borio, W.B. English; A.J. Filardo "A Tale of Two Perspectives: Old or New Challenges for Monetary Policy?” BIS Working Paper No. 127 (2003).

151 See, e.g. Frederic S. Mishkin "Monetary Policy Flexibility, Risk Management, and Financial Disruptions" Journal of Asian Economics 23 (June 2010). The model used by the European central Bank is a version of Frank Smets; Raf Wouters "An Estimated Stochastic Dynamic General Equilibrium Model of the Euro Area” ECB Working Paper No. 171 (August 2002).

152 Directive 2013/36/EU (CRD) and Regulation 575/2013 (CRR) are applicable to credit institutions and investment firms.

153 Actually, current rules on CSD favour the connection between CSDs and central Banks for purposes of cash settlements, investment in money assets, access to reserve accounts, etc. See articles 40, 46, and 59 of Regulation (EU) No. 909/2014 of the European Parliament and of the Council of 23 July 2014 on improving securities settlement in the European Union and on central securities depositories. 


\section{Shadow banking's preliminary implications for the Banking Union, Capital Markets Union, and EU institutional architecture}

At this point, a reasonable question is what does shadow banking have to do with the new architecture of the Banking Union, and the soon-to-come reforms of the Capital Markets Union. The answer is that shadow banking problems are not acknowledged by any of the two reforms, and yet they could prove the undoing of the new architecture.

This article has made clear that money/credit and capital markets are not separate entities. Major players in money markets are also major players in capital markets (actually, they benefit from being present in both), and the process of creating money-like liabilities is heavily reliant on capital market institutions. Yet the two major reforms resulting from the crisis continue to uphold the idea that there is such neat distinction, and that it can be used as a policymaking compass.

This is not to say that the Banking Union is not impressive, or that the Capital Markets Union is not promising, but that proponents of one and the other seem to be making policy as if they were closed compartments. The Banking Union is construed under a premise of intermediation and centralization: banking risks are in banks, and supervision and backstops should be centralized. ${ }^{154}$ The Capital Markets Union, on the other hand, follows a disintermediation, and de-centralization agenda, which tries to facilitate direct (and disintermediated) access by firms to capital 'markets' and investors. ${ }^{155}$ The Banking Union follows a regulatory agenda focused on soundness and stability; ${ }^{156}$ the Capital Markets Union follows a de-regulatory agenda focused on growth. ${ }^{157}$

The contrast is not significant only for the features that are highlighted, but for those that are sidestepped. Banking Union rules ignore 'markets'. Even the

154 In addition to supervision being centralized in the ECB by the SSM Regulation, and resolution in the Single Resolution Board, article 1 SRM Regulation relies Article 1 SRM Regulation provides that "The SRM shall be supported by a single resolution fund ('the Fund')", which is contingent upon an intergovernmental agreement, for the transfer of domestic funds to the SRF, and the gradual merger of those funds (and their allocation to national compartments of the SRF). The Intergovernmental Agreement (IGA) was signed in May 2014 by all Member States, except for Sweden and the UK (Council document 8457/14).

155 European Commission Communication. Action Plan on Building a Capital Markets Union. Brussels, 30. 9.2015 COM (2015) 468 final, pp. 7-11, 12-15.

156 See, e.g. recitals (16), (17), (22), (23), (25), (26) etc. SSM Regulation.

157 See European Commission Green Paper. Building a Capital Markets Union Brussels, 18.2.2015 COM(2015) 63 final at p. 2; Communication. Action Plan on Building a Capital Markets Union cit. pp. 2, 7. 
ECB's macroprudential tools focus on individual banks. ${ }^{158}$ They are also based on Basel Framework rules, ${ }^{159}$ which, even after reforms that enhance their macroprudential focus, their core is of microprudential inspiration, based on the safety of individual banks, not the 'market'. Conversely, the agenda of the Capital Markets Union completely sidesteps intermediaries, ${ }^{160}$ and seems to work under the assumption that markets can work on their own. ${ }^{161}$ Infrastructures that are critical to the functioning of credit markets (CCPs or CSDs) are only treated under capital markets proposals, which emphasize fund mobilization ${ }^{162}$ ). This 'fully intermediated' view of banking, and 'disintermediated' view of capital markets is not accurate. The previous Sections have shown that straddling the boundaries of capital and money markets is not a feat of quirky entities, but the bread-and-butter of the most important players (especially in Europe, which is characterized by universal banks).

Tackling shadow banking challenges in this context is made (even) more difficult by other factors endemic to the EU's institutional architecture. One is article 127 (6) of the Treaty on the Functioning of the European Union (TFEU), which clearly affects shadow banking's angle of the intermediaries, as it states that the Council may "confer specific tasks upon the European Central Bank concerning policies relating to the prudential supervision of credit institutions and other financial institutions with the exception of insurance undertakings". This provision sets a clear limit to the efforts to harmonize prudential rules to enhance consistency.

A second factor is the difficulty to find a legal balance between monetary and prudential policies at the level of the ECB. The previous section has shown that most sensible options to rein on the excesses of 'shadow' money markets require the combination and coordination of regulatory restrictions with central bank interventions. In addition, monetary policy and prudential goals are

158 Article 5 (2) SSM Regulation, which makes reference to capital requirements and countercyclical buffers for individual institutions.

159 See, e.g. articles 133-136 CRD.

160 The term "intermediary" or "intermediaries" is used a total of 3 times in the Commission Communication. See European Commission Communication. Action Plan on Building a Capital Markets Union cit.

161 Ibid pp. 7-15 (access by firms to the market), and pp. 18-21 (fostering retail and institutional investment).

162 Regulation (EU) No.648/2012 of the European Parliament and of the Council of 4 July 2012 on OTC derivatives, central counterparties and trade repositories, and Regulation (EU) No. 909/2014 of the European Parliament and of the Council of 23 July 2014 on improving securities settlement in the European Union and on central securities depositories, are partly inspired by prudential considerations, yet the Commission's Green paper still holds a view that focuses on the mobilization of funds. See European Commission Green Paper. Building a Capital Markets Union cit. pp.4-5. 
subject to complex equilibria. ${ }^{163}$ Yet SSM rules offer mixed signals. On one hand, they stipulate that the supervisory function will be 'independent' of monetary policy, ${ }^{164}$ on the other hand they subject the Supervisory Board decision to the ECB's Governing Council, ${ }^{165}$ which is constitutionally bound by the mandate to preserve price stability. ${ }^{166}$

Furthermore, recent studies suggest that the so-called risk-taking channel is very relevant for purposes of monetary policy implementation. ${ }^{167}$ The degree of control by the central bank over this channel depends on the degree of regulatory control it has over the entities that are part of it. In this regard, the ECB lacks control over entities (e.g. MMFs) and infrastructures (e.g. $\mathrm{CCPs} / \mathrm{CSDs}$ ) in the channel.

Furthermore, control is also limited by the degree of discretion the central bank has to undertake actions that do not immediately impact price stability, but may eliminate financial frictions that could compromise the channel in the future. ${ }^{168}$ The ECB's powers to intervene in money markets are limited by its mandate to ensure 'price stability'. ${ }^{169}$ This means that an action in pursuance of financial stability goals need to be justifiable also in terms of ensuring price stability, and cannot go beyond what is necessary to achieve that goal. ${ }^{170}$ Though in practice the Court has been ready to grant ample discretion ${ }^{171}$ to the ECB at a time of deflationary pressures, it is unclear whether the Court would be equally forgiving if the ECB were to intervene during boom years,

163 In the long-run, there is no such conflict, but this can materialize in the short-run, in the sequential implementation of the policies. See Marco Lamandini; David Ramos Muñoz; Javier Solana "The European Central Bank (ECB) as a Catalyst for Change in EU Law. Part 1: The ECB’s Mandates” ECB Working Paper Program (forthcoming 2016).

164 Article 25 SSM Regulation.

165 Article 26 SSM Regulation.

166 This is the 'primary' objective of the ECB, according to article 127 (1) TFEU. In fact, Article 26(8) of the SSM Regulation provides that " i]f the Governing Council objects to a draft decision [presented by the supervisory Board], it shall state the reasons for doing so in writing, in particular stating monetary policy concerns." (emphasis added).

167 Claudio Borio; Haibin Zhu "Capital regulation, risk-taking and monetary policy: a missing link in the transmission mechanism?” BIS Working Papers No. 268 (December 2008).

168 For a discussion of the role of financial frictions in introducing non-linearities in traditional macroeconomic models used for central bank policymaking purposes, see Frederick Mishkin “Monetary Policy Strategy: Lessons from the Crisis” NBER Working Paper Series WP16755 (2011).

169 Article 127 (1) TFEU.

170 This is the proportionality test enounced by the CJEU in Case C-62/14 Peter Gauweiler et al v Deutsche Bundestag, 16 June 2015, at 66 et seq.

171 Ibid at 68. 
by 'leaning against the wind', and constraining growth. Stabilizing money markets, including shadow banking, requires both types of interventions; otherwise ECB shadow banking policy would be limp, and shadow money markets will run amok again.

A third factor is the distribution of supervisory competences. Regulatory arbitrageurs thrive in the face of conflict and supervisory turf wars. ${ }^{172}$ In the EU typical tensions between 'field' supervisors (e.g. banking and securities) can be exacerbated by the division of tasks between EU and domestic supervisors, since the ECB is competent over 'significant credit institutions', and domestic supervisors over the other institutions ${ }^{173}$ plus markets (with ESMA in a coordinating role over markets, funds, or investment firms). This may reduce the risk of regulatory capture for large institutions, but may exacerbate it for smaller ones, or markets. Deprived of their more important supervisory responsibilities, domestic authorities (and lawmakers) may feel less inclined to use EU prudential policies as a blueprint for their domestic financial institutions, or to resist the temptation towards leniency, especially when that may facilitate access to credit for socially desirable goals. Given that small-scale, 'proximity' banking seems to be outside the focus of the Banking Union, its role should be part of the agenda of the Capital Markets Union if funds are to be mobilized, and no new risks are to emerge.

\section{Conclusions}

Solving shadow banking issues is a complex task, but one that, in essence, requires answering two simple questions, and following one simple command. The two questions are 'how much financial intermediation should be undertaken by entities that issue money-like liabilities?', and 'what degree of central

172 E.g. in the United States dealer banks benefitted from the SEC willingness to be their consolidating supervisor. Dealer banks were not subject to consolidated supervision by the Fed. Then, Directive 2002/87/EC on the Supplementary Supervision of credit institutions, insurance undertakings and investment firms in a financial conglomerate (Financial Conglomerate Directive, or FCD) was passed, and it could grant competences to an EU supervisor over as the consolidated supervisor of large US dealer banks. The FCD regime could be waived in the presence of an 'equivalent' supervisory regime, so pressure was put to develop such equivalent regime in the United States. The SEC did not have supervisory competences based on statutory rules, so it had to develop a regulatory regime without the threat of penalties in case of non-compliance: all it could do was to threat with expulsion. The results are soberly described in US SEC Office of Inspector General. SEC's Oversight of Bear Stearns and Related Entities: the Consolidated Supervised Entity Programme, Report No. 446-A September 25, 2008.

173 Article 6 (4) (7) SSM Regulation. 
control should public authorities retain over the creation of those liabilities, and in what form?' The command is 'turn the answer to these questions into clear policy choices, which can be translated into explicit legal provisions (please)'. Shadow banking can arise whenever market players wish to circumvent those policy choices. More often, however, it results when the above questions find no answer, or the answer is not translated into explicit choices or consistent legal provisions.

To be fair, legislatures and policymakers are not in an enviable position. The complexity of today's financial markets, and the globalization of capital flows, makes it impossible to assure full control over credit growth, and the ways it is funded by money-like liabilities. Anyone willing to make such pledge would simply lose credibility. However, it is one thing to acknowledge that, and quite another to say that public authorities are free of blame, or that nothing can be done.

Current money markets are a result of an experiment. This experiment was not decided at once, or in a single place, but it was an experiment nonetheless. One where public authorities gradually surrendered control over money creation. In a context where money is made of promises, all that needed to be done was to provide a system of public backstops (deposit insurance and central bank liquidity) over a 'core' category of liabilities (deposits), and the support of legal institutions for private players to create a 'periphery' of such liabilities (securitization and repos). This meant that central banks could lose track of the size and shape of the markets that emerged, and the institutional structures underpinning them. They could even stop controlling the quantity of core liabilities: interest rates could take care of inflation; capital requirements could take care of leverage (and asset bubbles), at least, this was the bet.

That bet (do we need to say it?) proved wrong. In what concerns intermediaries, capital and other prudential requirements can only restrain leverage if they are imposed upon all entities capable of creating money-like liabilities and intermediating credit. Policymakers underestimated market players' ingenuity, but they underestimated even more domestic legislatures' appetite for playing 'designer-in-chief', and their willingness to facilitate access to credit at the expense of soundness and stability. In what concerns money markets, it is difficult to send a clear signal that credit-creation using money markets should be constrained if policymakers refuse themselves the tools to restrain it (e.g. by sticking to narrow monetary mandates) and show unflagging support for the legal institutions that help to de-centralize the process (repos' bankruptcy protection, securitization's bankruptcy-remoteness), without any attempts to claw-back control.

Any meaningful reform of banking/credit and capital markets needs to address the processes that straddle the two markets. This is what shadow banking is 
about. For starters, any reformulation of prudential requirements should begin not by complicating their substance, but by clarifying their scope of application, which should encompass all entities that engage in maturity transformation, and, more generally, credit intermediation. This would require applying the rules that the scope of application of the rules should depend on factors such as the activity's intrinsic risk, or the entities' asset/liability structure, instead of the nature of the services rendered to the public. It would also (most likely) require divorcing prudential rules from consumer/investor protection and market conduct rules. This would not only improve operational efficiency, but legal consistency.

Some entities could still benefit from a less exacting regime (e.g. simplified capital/leverage requirements), but this would be based on explicit policy choices that weigh financial stability versus other social goals, and are translated into express legislative exemptions lawmakers can be accountable for. Beneficial treatment should be granted on the basis of lesser risk, or greater social benefit, not under the false pretense that the beneficiaries' activity is not credit intermediation, and thus should fall outside the scope of prudential rules. To do so only fragments the rules, and hinders their consistency as a whole body inspired by common principles.

The reform should also acknowledge the interplay between regulatory policy and central bank intervention in money markets, and the critical role that certain infrastructures have for these markets. The past crisis could have been worse had it not been for central banks' arsenal, but this will create a moral hazard problem in the future unless some degree of central control is restored over the markets where money-like claims are created and traded. Central banks can prescribe operational rules for collateral, but these need to be aligned with prudential rules on liquidity and haircuts, and accompanied by some degree of centralization of trades, clearing and settlement, all subject to prudential supervision. It is not a system as centralized as theoretical models of fractional reserve banking, but it is better than ignoring money-market dynamics beyond the narrow circle of central bank operations, as was the case before the crisis.

These reforms should be a centerpiece of current efforts to achieve a Banking Union and a Capital Markets Union. Yet the dividing lines chosen by EU policymakers show that we may be back to the old mistakes of the past: assuming that credit/money is intermediated without markets, and that capital markets function without intermediaries. It is inaccurate and dangerous. EU law poses challenges to the centralization and harmonization of prudential rules and tasks, to the consistency of prudential and monetary tasks, and to the coordination of domestic and EU supervisory levels. Yet most challenges are not insurmountable. They just require acknowledging the problem for what it is. 
In conclusion, concepts, including metaphoric ones, are important for the legal process, as they help to simplify and visualize complex problems. The trouble arises when concepts misrepresent or oversimplify the problem at hand. Sadly, this is what 'shadow banking' does. Not because it paints certain types of credit intermediation as shady, but because it treats the problem as marginal. Rather than 'in the shadow of' the financial system, it is front and center.

This article tries to paint a more realistic picture by acknowledging shadow banking precedents, and the tense relationship they reveal between money, finance and law. It is rare for shadow banking to be just a symptom of maverick financial intermediaries, without the backing of specific legal institutions and regulatory subsidies. The change is that now the 'parallel' system has become the core, but that only makes an honest assessment of the problem more necessary.

Reforms that do that will be no definitive antidote for future crises. Risk always finds a way. Yet they would create a more robust financial law for the future, rather than putting a bandage over the mistakes of the past. A less exciting task than bringing light to a world of darkness, perhaps, but one that would see shadow banking for the central problem that it is. Put another way, Aesop tells us a fable of a dog who carried a piece of meat; and, seeing his reflection in the water, tried to take the meat from the "other dog", and, in doing so, lost his own piece. For present purposes the moral cannot be better: "beware lest you lose the substance by grasping at the shadow". 